\title{
A review of the clinical utility of serum S100B protein levels in the assessment of traumatic brain injury
}

\author{
Eric Peter Thelin ${ }^{1,2,3}$ • David W. Nelson ${ }^{4,5}$ - Bo-Michael Bellander ${ }^{2,6}$
}

Received: 19 September 2016 / Accepted: 28 November 2016/Published online: 12 December 2016

(C) The Author(s) 2016. This article is published with open access at Springerlink.com

\begin{abstract}
Background In order to improve injury assessment of brain injuries, protein markers of pathophysiological processes and tissue fate have been introduced in the clinic. The most studied protein "biomarker" of cerebral damage in traumatic brain injury (TBI) is the protein S100B. The aim of this narrative review is to thoroughly analyze the properties and capabilities of this biomarker with focus on clinical utility in the assessment of patients suffering from TBI.

Results S100B has successfully been implemented in the clinic regionally (1) to screen mild TBI patients evaluating the need to perform a head computerized tomography, (2) to predict outcome in moderate-to-severe TBI patients, (3) to detect secondary injury development in brain-injured patients and (4) to evaluate treatment efficacy. The potential opportunities and pitfalls of S100B in the different areas usually refer to its
\end{abstract}

Eric Peter Thelin

eric.thelin@ki.se

1 Division of Neurosurgery, Department of Clinical Neurosciences, University of Cambridge, Cambridge Biomedical Campus, Cambridge, UK

2 Department of Clinical Neuroscience, Karolinska Institutet, Stockholm, Sweden

3 Neurosurgical Research Laboratory, Karolinska University Hospital, Building R2:02, S-171 76 Stockholm, Sweden

4 Division of Perioperative Medicine and Intensive Care (PMI), Section Neuro, Karolinska University Hospital, Stockholm, Sweden

5 Department of Physiology and Pharmacology, Section of Anesthesiology and Intensive Care, Karolinska Institutet, Stockholm, Sweden

6 Department of Neurosurgery, Karolinska University Hospital, Stockholm, Sweden specificity and sensitivity to detect and assess intracranial injury.

Conclusion Given some shortcomings that should be realized, S100B can be used as a versatile screening, monitoring and prediction tool in the management of TBI patients.

Keywords S100B - Traumatic brain injury - Outcome · Monitoring $\cdot$ Screening $\cdot$ Biomarker $\cdot$ Serum $\cdot$ Humans

\section{Introduction}

Traumatic brain injury (TBI) is a common cause of death and disability, primarily in the young but increasingly among the elderly [153]. The injury panorama stretches from the severely injured, unconscious patients in need of neuro-intensive care to the more common mildly injured patients, sometimes without any visual lesions. Many survivors, even from seemingly mild injuries, may suffer from permanent disabilities and be in need of long-term rehabilitation with high costs for society [56].

TBI is a complex disease and may change symptomatology over time [102]; it is heterogenic in nature and may contain a plethora of different hemorrhagic and non-hemorrhagic injures, both inside and outside the brain parenchyma. At admission to the hospital, the physicians often rely solely on a neurological examination and a computerized tomography (CT) scan, as other more advanced radiological options are unavailable in the acute care setting and monitoring tools are available only in specialized neuro-intensive care units (NICUs). Consequently, the assessment methods are often limited, and better surrogate markers of brain injury have been sought to help the treating clinician. In many fields of medicine, biological markers ("biomarkers") of injury have been introduced. A biomarker is defined as "A characteristic that is 
objectively measured and evaluated as an indicator of normal biological processes, pathogenic processes, or pharmacologic responses to a therapeutic intervention" [54]. It may be proteins, functioning as surrogate indicators of injury, such as troponin- $\mathrm{T}$ in the screening for myocardial infarction [60] and D-dimer for deep vein thrombosis [198]. While a number of potential markers of brain tissue fate (i.e., increasing levels of the specific markers indicating affected or dying cells) exist, the most studied protein biomarker of brain injury is S100B.

The first human TBI study of S100B's value as a serum biomarker of brain injury assessment was published by Ingebrigtsen and coworkers in 1995 [75], although increased S100B levels in cerebrospinal fluid (CSF) following various neurological disorders had been previously described in patients by Sindic et al. in 1982 [165]. Later on, S100B was shown to be sensitive enough to detect and assess different traumatic intracranial lesions, including cerebral contusions [144], subdural hematomas and traumatic subarachnoid hemorrhages [152], as well as epidural hematomas [189].

While several reviews currently exist, highlighting the role of S100B in both mild [193] and moderate-to-severe TBI [104], new aspects have evolved in this field such as the finding of S100B transportation through the newly discovered glymphatic system [141], implementation of the Scandinavian guidelines for TBI incorporating S100B [194] and improved kinetic modeling of S100B release from the injured brain [42].

This review aims to give the clinician a comprehensive overview of the utilities of S100B in the assessment of brain injury and may thus be used as a guide to interpret serum S100B samples in the treatment of both mild and moderate to severe TBI patients.

\section{The protein S100B}

The protein S100 was originally isolated from bovine brain almost 50 years ago and got the name from its $100 \%$ solubility in a saturated ammonium sulfate solution [108]. S100 is a relatively small protein, 9-14 $\mathrm{kDa}$, present physiologically mainly as different homodimers [36]. It belongs to a family of intracellular, calcium-binding proteins predominantly present in mature, perivascular astrocytes, but is also present to some extent in other cells in the central nervous system (CNS), including oligodendrocytes, neural progenitor cells and certain neuronal populations [39, 172]. In the CNS, the protein exists mainly as the homodimer S100BB or heterodimer S100AB [58, 76]. Together, these proteins make up the levels of what is usually referred to clinically as "S100B" (or sometimes "S100B Total"). Several other proteins of the S100 family exist, whose functions have been previously described in several review articles [37, 38, 84].
Ideally, a biomarker of brain injury should fulfill the following criteria according to prominent authors in the field [84, 130] (Table 1). Currently, no biomarker fulfills all the criteria, but as S100B is the most studied, we are learning how to interpret and assess it in different situations, thus minimizing and avoiding potential limitations.

\section{Functions of S100B}

S100B has several properties, previously reviewed [36-38, $49,106,196]$. Intracellularly, S100B is a normal part of calcium hemostasis, thereby transferring signals from second messengers [64]. S100B is also involved in cell differentiation and cell cycle progression [158], and it has been shown to inhibit apoptosis if applied in experimental conditions [25]. Extracellularly, in both normal physiology and during traumatic conditions, administered $\mathrm{S} 100 \mathrm{~B}$ promotes neurogenesis $[1,57]$ and neuronal plasticity $[103,120]$, performs neuromodulating actions and enhances processes involved in memory and learning $[43,83]$.

However, the effect and physiological functions of S100B have been shown to be concentration dependent, where lower concentrations (nanomolar levels) are beneficial and higher concentrations (micromolar levels) are correlated to harmful effects $[154,196]$. Escalating extracellular levels of S100B have been shown to result in neuronal dysfunction or cell death because of an inflammatory response that stimulates astrocytes and microglia to recruit and produce proinflammatory cytokines with a subsequent increase of the extracellular levels of calcium and activation of nitric oxide, with harmful effects $[69,89]$.

The different effects of S100B have been suggested to depend on the Receptor for Advanced Glycation End-products (RAGE), which is upregulated by S100B levels and may cause proinflammatory gene activation [38], although much is still unknown about how S100B exerts its biochemical properties.

Table 1 Suggested properties for biomarkers in traumatic brain injury

Demonstrate a high sensitivity and specificity for brain injury

Exhibit a passive release from the central nervous system (CNS) without any stimulated active release

Lack specific effects on CNS cells interfering with the initial injury

Useful to stratify patients by severity of injury and provide information about injury mechanisms

Have a rapid appearance in accessible biological fluids and an unlimited passage from the brain

Have well-defined bio-kinetic properties and monitor progress of disease and response to treatment

Predict functional outcome 


\section{Release and elimination of S100B}

In vitro studies reveal that astrocytes, when affected by trauma or metabolic distress [47], will release stored S100B, which has been measured extracellularly as fast as $15 \mathrm{~s}$ after a lesion is established [200]. The S100B mRNA concentration, as a sign of ongoing intracellular synthesis of the protein, will also increase shortly after injury [68]; thus, the concentrations measured in blood are from both secreted and newly synthesized origins. However, looking at the volumes of synthesized mRNA, the majority of the measured S100B in bodily fluids seems to come from dead or dying cerebral tissue.

It is known that the concentration of S100B in the CSF could be up to $100 \times$ higher than in serum [137]. A majority of the $\mathrm{S} 100 \mathrm{~B}$ is presumably released directly from the CSF to serum through the arachnoid villi, as the ratio between the CSF:serum of S100B is correlated, especially early after the TBI [51]. When the patient suffers from TBI, the blood-brain barrier (BBB) is disrupted, causing a leakage of proteins from the CSF with subsequent cerebral deterioration and edema formation [100]. The ratio of albumin between CSF:serum $\left(\mathrm{Q}_{\mathrm{A}}\right)$ is often used to quantify the degree of BBB disruption [184]. Some authors claim that S100B is released into the serum through the disrupted $\mathrm{BBB}[80,81,99]$; thus, it is a good marker of BBB permeability [20, 97]. However, the studies supporting S100B as a marker solely for BBB integrity are limited in sample size, use osmotic or chemo-therapy in non-TBI patients to disrupt the BBB and are not focused on the complex BBB disruption present following traumatic conditions. Studies that focus on TBI patients do not show any correlation between a disrupted $\mathrm{BBB}$, using $\mathrm{Q}_{\mathrm{A}}$, and the peak serum levels of S100B [14] or by using a ratio of the CSF and serum $S 100 B$ compared to $Q_{A}$ [87], hence indicating a better correlation between actual injury and S100B levels and not to the degree of BBB disruption.

Furthermore, a route between the para-arterial influx, interstitial fluid of the brain, cerebrospinal fluid and venous outflow has recently been discovered, entitled the glymphatic system because of the connection between glial cells and aquaporin-4-dependent paravascular pathways (mimicking a lymphatic drainage from the brain) [71]. It has recently been shown that this system probably plays a very important role in the outflow of S100B from the brain, which could explain the discrepancies found in TBI studies looking at correlations between BBB integrity and S100B release [141]. Recent findings in animal models suggest that $\mathrm{S100B}$, as well as the biomarkers neuron-specific enolase (NSE) and glial fibrillary acidic protein (GFAP), are released through the glymphatic drainage, independent of BBB permeability [141]. If this is confirmed, it constitutes several challenges to the interpretation of the serum levels of protein biomarkers in humans. First, the recently discovered glymphatic system is, so far, impossible to monitor in vivo in humans, and no surrogate marker to assess the glymphatic system exists today. This will make it difficult to evaluate whether the glymphatic system plays the same role in humans as in animal brain biomarker release. Second, in studies from the Nedergaard group that discovered the glymphatic system [70, 71], the aquaporin-4containing podocytes of perivascular astrocytes depolarize for up to 4 weeks following experimental traumatic brain injury, resulting in a disrupted glymphatic clearance. In theory, this might also affect the biomarker release from the injured brain in humans. Third, the glymphatic drainage has been shown to be affected if CSF is drained by pharmaceutical compounds as well as if sleep is affected. Draining the CSF and sedating patients (possibly similar to sleep) are two common treatment modalities in the NICU for severely brain injured patients to maintain adequate intracranial pressure. Thus, different actions in the NICU will have an effect on the release of $\mathrm{S} 100 \mathrm{~B}$ in serum.

Systemically, S100B has been shown to be excreted and eliminated 100\% through the kidneys [195]. Patients with renal failure have higher baseline S100B levels compared to healthy controls [107], which should be taken into consideration when assessing S100B in these patients. However, the mild to moderate kidney impairment often seen in trauma patients has not been shown to significantly affect S100B levels in serum [79].

In summary, S100B is released from the CSF to serum, but this drainage could be affected by the glymphatic clearance as well as the BBB permeability. Therefore, although it is seemingly passive, it may in theory be altered by different factors.

\section{Extracranial sources of S100B}

There are several known extracerebral sources of protein S100B, such as Langerhan's cells, adipocytes, epithelial cells, cardiac and skeletal muscle cells, and chondrocytes [58]. According to researchers involved in the Human Protein Atlas, S100B mRNA is only 1.44 times more expressed in the cerebral cortex compared to adipose tissue, the second most common tissue containing S100B [166]. This could be compared with GFAP mRNA, which is 374.81 times more common in the brain compared to adipose tissue, the second most common source for that protein as well. Notably, GFAPbrain specificity is only "beaten" by oligodendrocytic myelin paranodal and inner loop protein (OPALIN), with mRNA 541.99 times more common in the brain than in any other analyzed tissue [166]. Patients who suffer from trauma, presenting multiple injuries to the thorax, extremities and abdominal organs without any identified damages to the central nervous system, have been shown to exhibit elevated S100B concentrations in serum [7, 138, 155, 190]. However, S100B released from an extracerebral origin appears to have a faster clearance than S100B released from the CNS [33, 134, 157], 
while some authors suggest a very limited contribution from extracranial sources [139]. In our group, we have also seen that extracranial trauma contributes independently to increased serum levels of S100B [182]. When conducting a sliding window over time, we found that the early peak and values $<12 \mathrm{~h}$ after trauma are poorly correlated to outcome [180]. After $12 \mathrm{~h}$ there is an increase in relations to outcome, which peaks around the end of day 1 [179], which is congruent with the kinetic modeling where the main injury peak is found at $27 \mathrm{~h} \mathrm{[42].} \mathrm{The} \mathrm{early} \mathrm{or} \mathrm{near} \mathrm{immediate} \mathrm{peak} \mathrm{is} \mathrm{as-}$ sumed to be of extra-cranial origin as it is correlated to multitrauma and, in contrast to the gamma-variate kinetics of the main peak, appears to follow a first-order kinetic with rapid decay [42].

In summary, while possible extracranial sources should be taken into consideration when assessing TBI patients [135], repeated sampling after $12 \mathrm{~h}$ should exclude several of these confounding factors. This, however, has implications for the use of S100B as an early warning sign in mild TBI.

\section{Half-life of S100B}

It is difficult to assess the half-life of S100B in serum after TBI since there will be a continuous release of the protein from the damaged brain and perhaps a contribution from the CSF due to a disruption of the BBB [81], outflow through the glymphatic system [141] and ongoing cerebral synthesis and/or active secretion [47, 68]. The half-life of S100B has been shown to be in the range of 60 to $120 \mathrm{~min}$ in patients with TBI $[73,77]$ and $90 \mathrm{~min}$ in patients suffering from malignant melanoma [48]. Another more controlled method makes it as short as $25 \mathrm{~min}$ [79], calculated from patients undergoing coronary artery bypass grafting not suffering from any evident brain injury.

In aggregate, the net amount of S100B in serum will thus be the summed effect of the rate of influx and the rate of elimination. As the serum half-life of S100B is short, an extended elevation of S100B indicates an ongoing influx. We have recently shown this to be well fitted to the gamma variate function [42] in patients with TBI. The peak and area under the curve of the increase appear to correspond to the extent of the damage sustained [179].

\section{Assays to analyze S100B}

There are several available assay kits to measure S100B that are used in clinics and laboratories. An advantage of S100B is that it is stable and relatively unaffected by storing, changes in temperature and freeze-thaw cycles [146], which greatly facilitate the handling of the protein and reliability of the analyses. Another advantage with S100B is that it is not affected by hemolysis in the sample [13], making it a robust sample to use in the acute setting. ELISA has become the gold standard for measuring S100B in laboratories, and kits are commercially available from several different manufacturers (Sangtec, Italy; CanAG Diagnostics, Sweden; Syn X Pharma Inc. Nanogen, USA, to name a few). Unfortunately, ELISA assays take $4-6 \mathrm{~h}$ to run and generally present higher inter- and intracoefficients of variation (CVs) compared to clinical assays, resulting in a worse functional sensitivity of the devices [167], making them difficult to use in the clinic.

In clinical settings, the two most frequently used systems are the quantitative automated luminometric immunoassay LIAISON-mat S100 system (Diasorin, Sangtec, Italy) and the electrochemiluminescence immunoassay (Elecsys S100B®; Roche Diagnostics, Penzberg, Germany). The LIAISON system was primarily designed to detect and screen for S100B in malignant melanoma and other tumors and is thus not designed for quick analyses [116]. The Elecsys system and the new automated Cobas ${ }^{\circledR}$ system from Roche Diagnostics are increasing in popularity since they take only $18 \mathrm{~min}$ to run a serum sample, making it more suitable for TBI and possible for both emergency room (ER) and NICU use [167].

New point-of-care bedside devices are being developed [122] to be able to swiftly detect elevations of S100B. These kits could be deployed on the battlefield or in ambulances to quickly assess S100B levels above certain thresholds using bio-sensors.

\section{Clinical use of S100B}

A number of review articles have thoroughly analyzed different aspects of the clinical utilities of S100B [10, 19, 44, 84, 88, 91, 104, 159].

S100B from extracranial sources has long been used to monitor the advancement and evaluate the efficacy of therapy of melanocytic tumors $[40,82,168]$. As an interesting note, persons with darker skin have higher serum levels of S100B (median $0.14 \mu \mathrm{g} / \mathrm{l}$ ) as compared to persons with brighter skin (median $0.07 \mu \mathrm{g} / \mathrm{l}$ ) [15], presumably due to a higher metabolic activity in melanocytes in the former group [6]. This might be of importance when calculating outcome from TBI in patients with darker skin, as higher serum levels may be falsely interpreted as elevated, resulting in an unnecessary CT scan in mild TBI.

A clinical role has also been shown for different cerebral conditions, including stroke [23, 45], global ischemia [115, 195], neurodegenerative disorders such as MS and Alzheimer's disease [154], spontaneous subarachnoid hemorrhage [109, 123, 156, 175] and cerebral vasospasm [123]. Nevertheless, it is in the field of TBI where it has been mostly studied. 
All traumatic cerebral injuries have been shown to increase S100B in serum, but focal injuries, such as cerebral contusions and subdural hematomas, present higher levels as compared to diffuse injuries [67], and contusion volumes have been directly correlated to serum levels of S100B [140, 144]. This further stresses that the amount of tissue affected is much more important than the exact spatial location when assessing brain injury using S100B. Thus, the importance of combining S100B with proper imaging is necessary to visualize anatomical localization of the injury.

However, S100B has been shown to be able to stratify patients by injury severity, as can be seen in studies showing low S100B levels in mild TBI (GCS14-15) and escalating levels in moderate (GCS9-13) and severe (GCS3-8) TBI $[67,152]$. The most common CT classification of injury is the Marshall CT classification [101], where S100B has been shown to increase in the focal, more severe, lesions compared to more diffuse injuries $[90,140]$. Other classifications of injury include the Rotterdam CT score [98] and Stockholm CT score [117], where an increasing sum is associated with a more unfavorable outcome, also showing a correlation to increased serum levels of S100B as the injury becomes more severe [179]. More novel techniques for image outcome following traumatic brain injury exist; one of them is functional MRI, where levels of S100B in serum have been shown to correlate to the extent of disrupted connectivity in the default mode networks [183].

\section{S100B to screen for intracranial pathology in adult, mild TBI patients}

The vast majority (estimated up to 95\%) of all TBI cases present as mild, defined as a Glasgow Coma Scale (GCS) score of 14-15 [29], and are common patients in the emergency room (ER). The physician in the ER is often presented with the challenge of how to assess these patients as they are often intoxicated; up to $50 \%$ of mild TBI patients suffer from alcohol intoxication [125] and could have problems remembering what exactly happened as well as whether any post-traumatic symptoms occurred, something that could be difficult even for the sober.

Moreover, some of these patients may develop intracranial hematomas in need of surgical evacuation or intracranial monitoring. To detect these lesions, a computerized tomography (CT) scan of the brain is the preferred radiological choice [170]. However, these should be minimized as they are accompanied by a significant dose of radiation and therefore a slightly increased risk of cancer, and they may even have an effect on cognitive functions later in life [24, 59]. To determine which patients to scan, specific guidelines have been presented, such as the Canadian CT rule [173], the NEXUSII [111] and the Scandinavian CT guidelines from 2000 [74].
Using the Scandinavian guidelines from 2000, the sensitivity to detect an intracranial lesion is $96 \%$, but the specificity only $53 \%$, similar to the other guidelines [171]. Therefore, even if few lesions are missed using CT scanning, many unnecessary CT scans are performed with excess radiation and costs as a consequence. Furthermore, scanning intoxicated patients may require sedation and intubation, which could be potentially harmful for the patient.

The introduction of S100B sampling in the ER has introduced a way to potentially screen which patients are in need of a CT scan. A meta-analysis on mild TBI and S100B, including 2,466 patients from 12 articles, states that the pooled negative predictive value (NPV) was more than 99\% (CI 98\%-100\%) with a sensitivity of $97 \%$ in S100B detecting CT-visual brain pathology, using $0.10 \mu \mathrm{g} / \mathrm{l}$ as the cutoff [193]. This sensitivity and NPV make S100B superior to D-dimer, for example, in detecting pulmonary embolism and deep vein thrombosis (NPV: 92\%) [198] and troponin-T (NPV: 96\%) [60] in detecting myocardial infarction. The authors, however, do stress the importance of acquiring the sample early, within $6 \mathrm{~h}$, after a mild TBI (due to the short half-life) and not using it in patients with extracranial injuries, since these patients will present S100B from extracranial sources and would thus lower the specificity for intracranial lesions [193].

This meta-analysis formed the foundation for the new Scandinavian CT guidelines for mild and moderate TBI from 2013 [192]. These guidelines today assist physicians and personnel in the ERs in several Scandinavian hospitals to better determine which mild TBI patients are in need of a head CT scan by acquiring a serum sample of S100B. If the concentration is less than $0.10 \mu \mathrm{g} / \mathrm{l}$ within $6 \mathrm{~h}$ after trauma and the patient is suffering from a mild TBI without extracranial trauma and other risk factors, not performing a head CT scan could be considered [192]. In theory, it is estimated that this could reduce the number of unnecessary $\mathrm{CT}$ investigations by about a third in the emergency departments with more effective resource allocation.

A risk that must be avoided and has been seen locally is to use S100B indiscriminately as a general screening tool to identify those in need of a CT, not considering the clinical indication and possible extra-cranial trauma-related peaks, as this may increase the number of CTs done instead of decreasing it. One should bear in mind though that not all cerebral pathology is visible on CT scans [93]; some lesions appear only on magnetic resonance imaging (MRI) or the more accurate diffuse tensor imaging (DTI). Authors are suggesting that some of these "false-positive" S100B levels might indicate lesions only seen on MRI [72], and as more sensitive radiological techniques become available, perhaps the specificity for S100B to detect intracranial lesions will increase. Some of the CT scans in studies included in the metaanalysis that formed the basis of the Scandinavian guidelines [193] could also have been performed too early (within 
$90 \mathrm{~min}$ ) and thus may have missed the natural progression of cerebral contusions [199]. An inherent risk we have noted when using S100B to identify patients with mild TBI requiring a CT scan in the ER is if instead it is used as triage prior to clinical evaluation. This will recruit an unintended cohort of patients often with trauma-related S100B levels, increasing the risk of false-positive results and the risk of unnecessary CT scans. As mentioned, another factor that may cause "falsely" increased S100B levels is darker skin [15], something that may need to be further evaluated and possibly incorporated into current guidelines.

Theoretically and shortly after injury, the sensitivity of identifying a brain injury requiring a CT scan using S100B with a relatively low cutoff (i.e., $0.1 \mu \mathrm{g} / \mathrm{l}$ ) is high, as a substantial amount of S100B will be released from the brain, as well as from potential extracranial sources [182]; however, this specific cutoff also results in a low specificity of intracranial injury if sampled too early. As time progresses, the short serum half-life of S100B will lead to a high wash-out of $\mathrm{S} 100 \mathrm{~B}$, especially if there is no ongoing intracranial release or progressing injury.

A recent retrospective external validation of the new Scandinavian CT guidelines from 2013 was published last year [194], where the authors noticed that in a cohort of 662 patients, the guidelines had a sensitivity of $97 \%$ and a specificity of $34 \%$, and this resulted in a CT reduction of $32 \%$ if applied [194]. One patient had an S100B level $<0.1 \mu \mathrm{g} / 1$ and a small cortical contusion, but this patient presented with a mild TBI and perhaps would not have had a CT performed if other guidelines had been followed. Furthermore, the patient fully recovered shortly after injury. Another recent report from Calcagnile and co-workers revealed that the implementation of S100B to screen for intracranial lesions led to a cost reduction of $39 €$ per patient in their department, with theoretical savings of up to $70 €$ per patient if implemented correctly according to the guidelines [27].

In summary, we conclude that, given the above caveats concerning specificity, sensitivity and usage, the current suggested cutoff levels appear to provide a reasonable and clinically useful tool to detect CT visible intracranial pathology in mild TBI patients. Given the introduction of the Scandinavian guidelines, the effects of this transition will however need to be monitored for safety.

\section{Potentially missed lesions in mild TBI because of the 2013 Scandinavian guidelines}

Recently, a new meta-analysis was published including $\mathrm{n}=$ 3,893 patients [63], suggesting higher cutoff levels (0.16$0.20 \mu \mathrm{g} / \mathrm{l}$ ) to improve the specificity (to $50.69 \%$ ) to detect CT-visible intracranial pathology. However, as we approach $6 \mathrm{~h}$ after trauma, the lower cutoff of $0.1 \mu \mathrm{g} / \mathrm{l}$ is probably better as it appears to assure an acceptable level to detect injury. By choosing a higher cutoff, we increase the risk of missing epidural hematomas, for example, which often present with only marginally elevated S100B levels [189]. While Undén and coworkers did not find any patient with EDH to have an S100B lower than $0.14 \mu \mathrm{g} / 1$ [189], others have detected S100B levels well below $0.1 \mu \mathrm{g} / 1$ in these patients [5, 202]. However, in these studies the Scandinavian guidelines were not implemented, and the exact time after trauma was unknown, thus confounding interpretation of these results. As the cerebral parenchyma is only marginally affected in the early stages of a progressing EDH, lower brain biomarker levels are expected. Presumably, some of the early S100B contribution in these cases could come from associated cranial fractures [131].

That even $0.1 \mu \mathrm{g} / \mathrm{l}$ of S100B might miss patients with positive CT findings was highlighted in the external validations of the Scandinavian CT guidelines [194]; however, these guidelines appear to have a similar capability to discriminate those in need of CT scans as other CT guidelines for mild TBI used worldwide [171].

In summary, the S100B cutoff to detect intracranial pathology in mild TBI should not be used in isolation, but as an integrated part of the assessment including clinical evaluation in order not to miss potentially harmful lesions, in concordance with the Scandinavian guidelines.

\section{S100B to assess sports-related brain injuries}

Another field where mild, and often repetitive, TBI is common is in contact sports. Here, the unreported incidence may be higher than 600 per 100,000 people per year compared to the 200 per 100,000 reported incidence [29]. While a minimal number of these accidents results in verifiable cerebral lesions that need extensive medical attention, several athletes suffer from post-concussion-like symptoms (including chronic traumatic encephalopathy, CTE [126]) affecting somatic, affective and cognitive capabilities, sometimes persistent, preventing return to work and other daily activities [29].

Several studies have highlighted the role of S100B as a marker of brain injury severity in this group that was recently reviewed [129, 161], where S100B levels, among other things, were correlated to the ability to return to work [174]. Again, it should also be noted that S100B is increased in athletes without any obvious head injury, such as swimmers and marathon runners [161], which could be due to extracranial release, representing a confounder especially in mild head injuries where a limited amount of brain parenchyma might be affected.

\section{Clinical use of S100B in children}

Perhaps the area that may best benefit from a surrogate marker to rule out unnecessary CT scanning is the pediatric 
population, as radiation emanating from CTs has been shown to be particularly harmful in this group $[24,59]$. In fact, for a 1 -year-old child, studies estimate the risk of developing a lethal malignancy from a single $\mathrm{CT}$ of the brain to be as high as 1:1500 compared with 1:5000 for a 10-year-old child [24]. Additionally, S100B is neurotrophic, and levels in serum are generally increased in the pediatric population with a growing $\mathrm{CNS}$, thus presenting great variation of normal reference levels up to 15 years of age $[8,21,30]$. While higher cutoffs have been suggested for $0-24$ month olds $(0.35-0.23 \mu \mathrm{g} / \mathrm{l})$ [22], the Scandinavian Neurotrauma Committee recently found it presently not possible to implement S100B using a similar cutoff approach as used in adults to detect patients eligible for CT scanning in children [9]. More knowledge of age-dependent normal values need to be evaluated before S100B can be used as a safe guide for decision making concerning CT scanning in children. Moreover, S100B is easy to obtain via both capillary and urinary samples, both representing ways to detect the protein $[8,18]$. Not having to use venipuncture could be preferable for children. However, the utility of urinary S100B levels warrants further research and evaluation.

In more severe pediatric TBI cases, temporal profiles of subsequent samples of S100B in serum, referred to as a trajectory analysis, with increasing serum levels have a higher risk of unfavorable outcome compared to patients with subsequent serum concentrations in steady decline [17]. Thus, S100B may represent a similar surrogate marker of injury for outcome prediction and monitoring to detect secondary injuries as in the adult population. Other areas where S100B might provide important information about cerebral injuries are in the assessment of preterm newborns [163] and following hypoxic-ischemic injuries [53], recently reviewed respectively.

In summary, while S100B could benefit the pediatric population in the assessment of brain injury, more research is necessary before possible guideline implementation.

\section{S100B and outcome prediction in moderate-to-severe TBI in adults}

Several reviews have analyzed how S100B may be utilized in moderate and severe TBI patients $[16,49,66,86,92,96,130$, $147,162,176,186]$.

As severely brain injured patients enter the emergency department and the intensive care unit, they are often sedated and/or intubated making neurological assessments problematic. While CT examinations aid in the diagnosis and surgical planning, it is often difficult to fully predict the outcome of these patients [114]. Thus, a marker of brain tissue fate that may guide initial treatment and resources for patients in most urgent need in this critical phase is highly sought.
One of the latest reviews of S100B from 2013 includes a meta-analysis of 39 studies, including a total of 1,862 patients [104]. The authors found that serum levels between $2.16 \mu \mathrm{g} / 1$ and $14.0 \mu \mathrm{g} / \mathrm{l}$ predicted an unfavorable outcome, defined as a Glasgow Outcome Score (GOS) of 1 (death), 2 (vegetative state) or 3 (severe disability), and similar serum levels in six of the included studies were associated with mortality [104]. This wide concentration range is a huge problem for standardization and accurate cutoffs for outcome prediction. One of the major reasons for this, which is also discussed by the authors of the review, is the difference in sampling time in the studies. The optimal time for collecting S100B to predict outcome after trauma in moderate-to-severe TBI has been a matter of intense discussions. In several studies, the initial sample of serum S100B after trauma is considered the most important for outcome prediction [77, 136, 147, 152]. Later time frames have also been suggested to have clinical significance, ranging from within $6 \mathrm{~h}$ [201], 6 to $12 \mathrm{~h} \mathrm{[147],} \mathrm{within} 12 \mathrm{~h} \mathrm{[112],} \mathrm{after}$ $12 \mathrm{~h}$ [145], $24 \mathrm{~h}$ [50], within 42 to $79 \mathrm{~h}$ [67], within $48 \mathrm{~h} \mathrm{[134,}$ 197], $72 \mathrm{~h}$ [113] and finally up to $>84 \mathrm{~h}$ after trauma [134]. Thus, the serum concentration of S100B itself is of limited use to predict outcome if the time that has lapsed since the trauma is unknown.

Our group has shown, in a cohort of 265 NICU TBI patients, that the initial serum sample of S100B at admission has lower predicted accuracy toward outcome compared to later samples acquired approximately $24 \mathrm{~h}$ after admission [180]. The predictive accuracy of S100B is in fact $2-3 \times$ higher than age, pupil responsiveness or GCS at admission separately, all being known independent outcome predictors of injury suggested by the IMPACT (International Mission for Prognosis and Analysis of Clinical Trials in TBI) study group [114]. In a more recent study from our group, including the largest singlecenter patient cohort to date ( $\mathrm{n}=417$ NICU TBI patients), the best outcome prediction for S100B occurred at about $30 \mathrm{~h}$ after reported trauma, with pseudo-explained variance of about 25\% [179]. This latter predictive value is in congruence with our findings of a fitted kinetic model designed by our group, where the peak was found to be at $27 \mathrm{~h}$ [42]. In Fig. 1, we present a schematic overview of how we interpret the temporal release patterns of S100B and sources involved. The reason for the weak initial correlation between early S100B and outcome appears to be the result of the extracranial contribution of S100B "masking" the intracranial release. At $30 \mathrm{~h}$, patients with a long-term GOS 1 (death) had a median S100B of $1 \mu \mathrm{g} / \mathrm{l}$, GOS 3 (severe disability) $0.5 \mu \mathrm{g} / \mathrm{l}$, GOS 4 (moderate disability) $0.3 \mu \mathrm{g} / 1$ and GOS 5 (good recovery) $0.25 \mu \mathrm{g} / \mathrm{l}$, while it was not possible to detect specific serum levels significant for different GOS scores at admission [179].

The capabilities of S100B to predict outcome have led some authors to conclude that S100B could be used as a marker of brain death following injury $[41,164]$. However, we believe that there are several reasons why this is potentially 


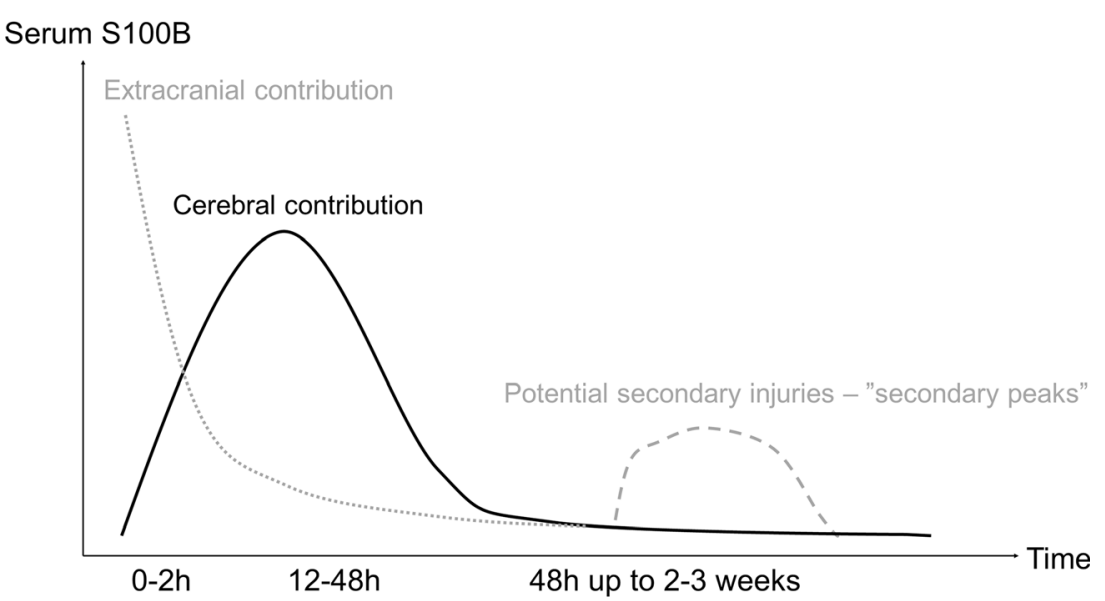

Fig. 1 Schematic overview of S100B release to serum. Schematic overview of the S100B release following severe TBI. Initially, there will be a great release of S100B from extracranial tissue to the serum (dotted, gray line), which will have a rapid wash-out the first hours after injury. While the cerebral release is more prolonged and shaped as a

gamma function, as suggested by Ercole et al. 2016 (black line), it will initially be "masked" by these extracranial contributions. Our black line illustrates an "uneventful" release of S100B in a patient suffering from severe TBI; however, patients may suffer from subsequent injuries resulting in "secondary peaks" of S100B (dashed, gray line)

dangerous and should be avoided. First, due to its low specificity of brain injury, other reasons for S100B increases should always be explored. We have for instance seen extreme increases of S100B in serum [135] in a patient with mild TBI and malignant melanoma. Second, the S100B levels suggested by authors promoting S100B as a marker for brain death diagnostics $(0.372 \mu \mathrm{g} / \mathrm{l}$ the first $24 \mathrm{~h})$ are levels in patients that we repeatedly have seen return to a favorable outcome 12 months after injury [180]. Third, we hypothesize that S100B needs perfusion through the affected tissue for it to be released to the blood and that this process will be non-existent in brain dead patients, making S100B levels unreliable. Our clinical experience, having followed S100B in close to 3,000 NICU patients (both TBI and subarachnoid hemorrhage patients), is that levels prior to verified brain death are highly variable. Undén and co-workers measured S100B during this condition and noticed that without adequate circulation (CPP, cerebral perfusion pressure) to the brain, because of a high ICP, considerably lower amounts of S100B will be released [191]. Hence, this is also probably why S100B is a poor biomarker in the early stages of thrombo-embolic stroke [45]. Our clinical experience also leads us to suspect that sharp S100B peaks after stroke may represent a reperfusion washout; however, this needs to be confirmed. Thus, S100B should not be considered as a tool to identify brain death or support decision-making concerning withholding of treatments in severe TBI cases.

In summary, after accounting for its limitations concerning the low specificity of early samples, S100B appears to be an important and useful predictor of functional outcome in moderate-to-severe TBI, stressing however that no compound prediction models in TBI to date are accurate enough to support end of life decisions per se. Instead, S100B should help physicians prioritize resources to patients and may be part of future patient stratification strategies.

\section{S100B as a monitoring marker of ongoing injury in adults}

Studies that subsequently sampled S100B during the hospital stay described scenarios where the levels of S100B continue to increase following TBI [85, 134], and these "climbers" have been shown to present an unfavorable outcome [177]. Moreover, patients without a steady decline of S100B in CSF and serum have been shown to present with worse outcome $[51,121,149]$. Serial S100B has even been suggested to outperform repeated radiological examinations to predict outcome [52]. Thus, there is a clinical interest in studying the kinetics of S100B following traumatic brain injury.

As the half-life of S100B in serum is short, a recent serum increase would theoretically correspond to a recent cerebral injury. We carefully mapped the kinetics of S100B in NICU TBI patients and noted that even small changes in time dramatically alter S100B levels and that the peak in the serum S100B concentration with seemingly unaffected wash-out is around $27 \mathrm{~h}$ after reported trauma [42]. Moreover, deviations from this normal curve as well as secondary peaks of S100B (Fig. 1) would presumably be a result of ongoing or new cerebral lesions.

Raabe and co-workers took daily S100B samples from their patients and found that a secondary increase of S100B $>0.5 \mu \mathrm{g} / \mathrm{l}$ significantly correlated to the development of a severe secondary injury, such as a cerebral infarction or hematoma progression [148]. Moreover, they found that this secondary increase of S100B influenced treatment and diagnosis in $21 \%$ of the cases. An additional study by Undén et al. revealed that increased levels of S100B were correlated with secondary neurological complications [188], but the authors could not demonstrate a robus correlation between the secondary peaks and these complications, or that these complications 
were associated with long-term outcome. We noted in a cohort of 250 NICU TBI patients that a secondary increase as subtle as $0.05 \mu \mathrm{g} / \mathrm{l}$ in patients sampled twice daily had a sensitivity of $80 \%$ and a specificity of $89 \%$ to detect secondary radiological pathological findings [181]. Moreover, these secondary increases in S100B were significant predictors of unfavorable outcome. In Fig. 2, we illustrate how serial sampling of S100B detected a secondary peak of $\mathrm{S} 100 \mathrm{~B}$, which correlated to the development of a right temporal infarction, a deterioration not detected using ICP monitoring. Our findings are similar to those of other TBI cohorts; several studies have shown a correlation between neurological deterioration and a secondary increase of S100B during the NICU stay, suggesting it to be a useful therapeutic tool closely related to pathophysiological mechanisms in TBI $[35,65,90]$.

We have shown that serum S100B has definable kinetic properties following TBI [42]. We are of the conviction that kinetic properties are a key strength of S100B as compared to certain other markers, such as GFAP, while GFAP, presumably because of its higher brain specificity, may be advantageous compared to S100B in screening mild TBI patients who require a CT in the ER [131]; the half-life of GFAP in serum is significantly longer than that of S100B ( $25 \mathrm{~min}$ vs. $<48 \mathrm{~h}$ ) [34, 79]. Thus, S100B should theoretically wash out quickly from the system if no S100B is contributed from an ongoing or evolving cerebral lesion, as it contains so much more S100B compared to other tissues. This is the primary reasons why it is difficult to establish outcome thresholds for S100B levels, as they will change rapidly in the serum during the first days following TBI [179], but at the same time it is this dynamic information content that strengthens their potential role as a monitoring marker and supports serial sampling [148, 181]. Therefore, using kinetic modeling, we defined the gammavariate curve that S100B is expected to follow [42]. This allows for reliably estimating the projected peak from any time point given that the time of trauma is known and provided that no secondary insults initiate a new release sequence.

In summary, these findings strengthen the role of S100B as a laboratory test for monitoring patients admitted to the NICU with frequent sampling preferable to detect potential injury progression that may prompt diagnostic and therapeutic actions.

\section{S100B as a surrogate marker for treatment efficacy}

Several groups, including ours, have found a correlation between ICP and serum S100B levels [14, 62, 124, 134, 181]. Since ICP is currently the most widely used surrogate marker to assess intracranial conditions, it supports the theory of $\mathrm{S} 100 \mathrm{~B}$ as a marker to guide treatment in the NICU.

Preclinically, S100B has been shown to be useful in determining the success of ischemic stroke treatment in rabbits [203]. Clinically, S100B has been used as a marker to validate the treatment effect in TBI patients between hypertonic salinedextran (HSD) and normal saline, where the HSD group presented lower levels, presumably indicating a less affected brain parenchyma [11]. During procedures such as hypothermia treatment following cardiac arrest [110], carotid endarterectomy [3] and cardiac surgery [187] and hyperbaric oxygen therapy following TBI [178], S100B levels in serum may be used to detect and treat any ongoing cerebral injury. Moreover, in clinical depression, S100B has been shown to be able to predict treatment response [4] and extra-cranially, as mentioned, to follow the treatment of malignant melanoma [40].

Currently, there are no pharmaceutical treatments to date that specifically target the underlying pathophysiology in TBI as all large placebo controlled randomized control trials have failed to show significant treatment efficacy [61], including, e.g., methyl-prednisolone [150], progesterone [205] and erythropoietin [119]. One of the reasons these trials have failed is believed to be a lack of methods to validate the therapeutic effect and instead focus predominantly on late outcomes, which may be influenced by a multitude of factors, thus introducing noise and possibly drowning possible treatment effects. In a recent, smaller study of erythropoietin in human TBI, S100B was used as a proxy of treatment effect with decreasing levels seen in patients treated with the drug vs. placebo, thus suggesting a lesser extent of tissue injury [94].

In summary, by introducing serum biomarkers such as S100B in future pharmaceutical trials, as well as better radiological markers [28], it may be possible to better monitor surrogate markers of effect in relation to specific pharmacological treatments.

\section{Other protein biomarkers of brain tissue fate}

There are several other theoretically brain-specific proteins that are used as biomarkers to assess brain injury [206]. Here, we focus briefly on some of the most studied in the context of S100B.

\section{Neuron-specific enolase (NSE)}

The second most published biomarker of brain injury is NSE. NSE is an iso-enzyme of enolase located primarily in the cytoplasm of neurons, involved in glycolysis by transforming 2-phosphoglycerate into phosphoenolpyruvate. When released in blood, it has a half-life of approximately $24 \mathrm{~h}$ in patients not affected by brain injury, to $48 \mathrm{~h}$ in patients suffering from brain injury $[73,78,160]$. Recent reviews and metaanalyses highlight its properties as an independent marker of functional outcome and mortality [31], albeit it being inferior to S100B [105]. The main limitation of NSE is its presence in red blood cells, causing problems in serum analyses in the 

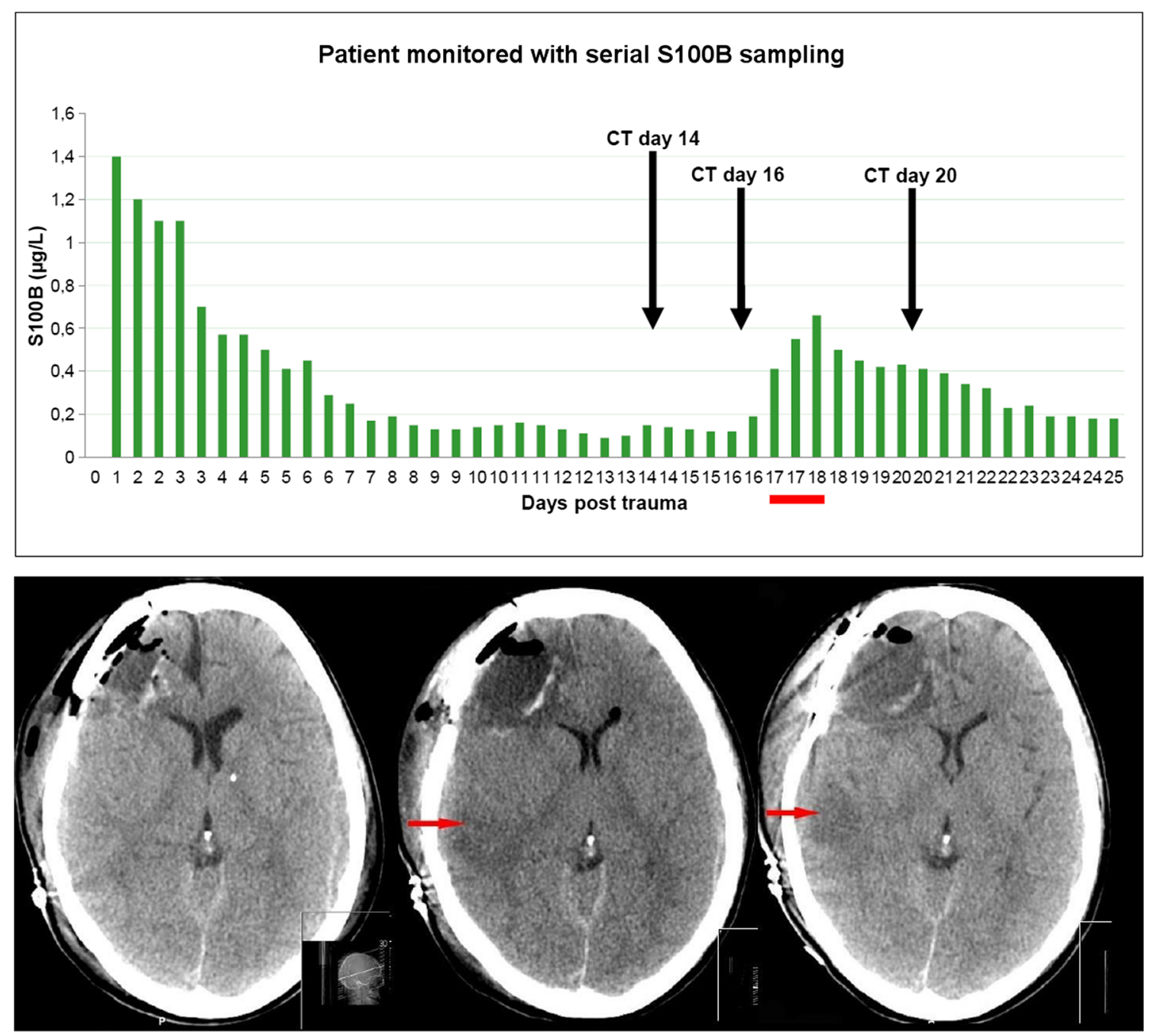

Day 14

Day 16

Day 20

Fig. 2 S100B monitoring of a TBI patient. The patient was monitored with subsequent sampling of S100B (twice per day, $y$-axis $\mu \mathrm{g} / \mathrm{l}$ of S100B and $\mathrm{x}$-axis days after trauma) illustrating an initial decline the first days following trauma approaching baseline levels. However, at day 16-18

case of hemolysis [46]. While modern techniques may try to adjust for this [185], hemolysis will often cause "false increases" of NSE making it difficult to assess in the emergency and NICU setting. In our group, we recently compared S100B and NSE and found that S100B was a better outcome predictor overall, with NSE only predicting mortality [179]. Importantly, despite NSE originating from neurons as opposed to astrocytes, a high covariance between S100B and NSE was seen. This also explains why it did not provide any additional information over S100B toward outcome prediction. Moreover, while an extracranial contribution from multitrauma was evident for S100B, this normalized within $12 \mathrm{~h}$. However, the correlation of NSE levels to multitrauma extends past $72 \mathrm{~h}$. This could theoretically be due to its longer half-life, but also a contribution of NSE from trauma-related hematomas is possible [179]. (bar), there is a secondary peak of $\mathrm{S} 100 \mathrm{~B}$ that correlates to the development of a right temporal infarction as seen on computerized tomography (arrows)

\section{Glial fibrillary acidic protein (GFAP)}

GFAP is an intermediate filament cytoskeleton protein primarily found in astrocytes; thus, it shares an origin with S100B. However, compared to S100B, GFAP is more brain specific $[133,166]$, which is probably why one study found a greater specificity in detecting CT-verifiable lesions in mild TBI patients compared to S100B in the presence of extracranial injury (5\% vs. 55\%) [131]. While kinetic studies have revealed a prolonged release and higher levels in mild TBI patients with CT lesions [127], no definitive results exist on the in vivo halflife. In vitro studies put the half-life of GFAP somewhere between 16-144 h for different subunits [32, 151, 169], while one clinical study suggested it is $<48 \mathrm{~h}$ in serum [34]. Although GFAP has been shown to be elevated in patients needing neurosurgical intervention [127], it has not been as 
extensively studied as a monitoring marker as S100B. For outcome prediction in moderate-to-severe TBI, GFAP has been shown to exhibit similar outcome predictive capabilities as $\mathrm{S} 100 \mathrm{~B}$, and a combination of the two markers may improve outcome prediction models [132, 204]. In summary, while GFAP is a promising marker of brain injury in both mild and moderate-to-severe TBI, its kinetic profile and outcome predictive effect are less studied compared to S100B's.

\section{Ubiquitin C-terminal hydrolase L1 (UCH-L1)}

One of the newer serum brain biomarker candidates is UCHL1. UCH-L1 is a deubiquitinating enzyme modifying the cterminal adduct of the ubiquitin monomer present primarily in neurons. Pre-clinical studies have been very promising with increasing levels early after both TBI and stroke [95]. The half-life in serum has been shown to be $11 \mathrm{~h}$ in TBI patients [26]. In clinical studies, results show that it may be used to screen for CT-verifiable lesions in mild TBI, but presents less specificity than many studies using S100B [128, 143] and does not provide the same accuracy over time to assess brain injury as GFAP [127]. Moreover, in moderate-to-severe TBI, while UCH-L1 levels have been shown to predict outcome, they do not add significant independent information to more extensive outcome models [142].

\section{Neurofilament light (NF-L)}

Neurofilaments, the main components of the axonal cytoskeleton, consist of three chains, where the protein NF-L constitutes the smallest ( $68 \mathrm{kDa}$ ). CSF levels of NF-L are used as a biomarker in multiple sclerosis to monitor effect of treatment [55]. There are fewer studies on TBI, but it shows promising results as a potential marker of injury severity as CSF samples have been correlated to the extent of injury sustained during boxing [118]. The serum half-life of NF-L is presumably long, suggested to range up to 3 weeks [12]. In our group, we have shown that the serum level of NF-L is a predictor of outcome in moderate-to-severe TBI and adds independent information significantly different from S100B [2]. This is perhaps not surprising as it represents a very different tree of TBI pathophysiology than S100B. However, this biomarker is not particularly dynamic in the early TBI stages and may not be helpful for early prediction and monitoring purposes [2].

\section{Conclusions}

S100B levels in serum are a useful marker of brain tissue fate in TBI. Several difficult clinical situations, such as determining the need for CT scanning in mild TBI, monitoring unconscious TBI patients, predicting outcome and validating treatment effect, may be facilitated by the use of S100B. The emerging understanding of the kinetics of S100B may help avoid pitfalls and increase its utility. Despite its shortcomings, and if appropriately used, S100B is a valuable and yet underused tool for clinicians managing TBI patients. Future research should focus on understanding and discriminating the origin of ultra-early and later levels of S100B and on defining age-related reference values for the pediatric population. Furthermore, given the strong predictive value for outcome in more severely injured TBI patients, we suggest that future novel biomarker studies should be compared to S100B in multivariate analyses including other known predictors, such as the IMPACT variables.

\section{Compliance with ethical standards}

Funding Svenska läkaresällskapet (The Swedish Society of Medicine, SLS-587221) provided financial support to Eric Peter Thelin. The sponsor had no role in the design or conduct of this research.

Conflict of interest Eric P. Thelin has received a lecture honorarium once in 2013 from Roche Diagnostics concerning the implementation of the Scandinavian guidelines for initial management of minimal, mild and moderate head injuries in adults. These guidelines include S100B sampling so this could be considered to be a potential conflict of interest.

Apart from that, all authors certify that they have no affiliations with or involvement in any organization or entity with any financial interest (such as honoraria; educational grants; participation in speakers' bureaus; membership, employment, consultancies, stock ownership, or other equity interest; and expert testimony or patent-licensing arrangements) or non-financial interest (such as personal or professional relationships, affiliations, knowledge or beliefs) in the subject matter or materials discussed in this manuscript.

Studies with human participants This article does not contain any studies with human participants performed by any of the authors.

Open Access This article is distributed under the terms of the Creative Commons Attribution 4.0 International License (http:// creativecommons.org/licenses/by/4.0/), which permits unrestricted use, distribution, and reproduction in any medium, provided you give appropriate credit to the original author(s) and the source, provide a link to the Creative Commons license, and indicate if changes were made.

\section{References}

1. Ahlemeyer B, Beier H, Semkova I, Schaper C, Krieglstein J (2000) S-100beta protects cultured neurons against glutamateand staurosporine-induced damage and is involved in the antiapoptotic action of the $5 \mathrm{HT}(1 \mathrm{~A})$-receptor agonist, Bay $\mathrm{x}$ 3702. Brain Res 858:121-128

2. Al Nimer F, Thelin E, Nystrom H, Dring AM, Svenningsson A, Piehl F, Nelson DW, Bellander BM (2015) Comparative assessment of the prognostic value of biomarkers in traumatic brain injury reveals an independent role for serum levels of neurofilament light. PLoS One 10:e132177 
3. Aleksic M, Heckenkamp J, Reichert V, Gawenda M, Brunkwall J (2007) S-100B release during carotid endarterectomy under local anesthesia. Ann Vasc Surg 21:571-575

4. Ambree O, Bergink V, Grosse L, Alferink J, Drexhage HA, Rothermundt M, Arolt V, Birkenhager TK (2016) S100B serum levels predict treatment response in patients with melancholic depression. Int J Neuropsychopharmacol 19:pyv103

5. Anczykowski G, Kaczmarek J, Jankowski R, Guzniczak P (2011) The reference level of serum S-100B protein for poor prognosis in patients with intracranial extracerebral hematoma. EJIFCC 22:6678

6. Andersen KE, Maibach HI (1979) Black and white human skin differences. J Am Acad Dermatol 1:276-282

7. Anderson RE, Hansson LO, Nilsson O, Dijlai-Merzoug R, Settergren G (2001) High serum S100B levels for trauma patients without head injuries. Neurosurgery 48:1255-1258, discussion $1258-1260$

8. Astrand R, Romner B, Reinstrup P, Friis-Hansen L, Unden J (2012) Comparison between capillary, venous and arterial levels of protein S100B in patients with severe brain pathology. Clin Chem Lab Med 50:1055-1061

9. Astrand R, Rosenlund C, Unden J (2016) Scandinavian guidelines for initial management of minor and moderate head trauma in children. BMC Med 14:33

10. Astrand R, Unden J, Romner B (2013) Clinical use of the calciumbinding S100B protein. Methods Mol Biol 963:373-384

11. Baker AJ, Rhind SG, Morrison LJ, Black S, Crnko NT, Shek PN, Rizoli SB (2009) Resuscitation with hypertonic saline-dextran reduces serum biomarker levels and correlates with outcome in severe traumatic brain injury patients. J Neurotrauma 26:1227-1240

12. Barry DM, Millecamps S, Julien JP, Garcia ML (2007) New movements in neurofilament transport, turnover and disease. Exp Cell Res 313:2110-2120

13. Beaudeux JL, Leger P, Dequen L, Gandjbakhch I, Coriat P, Foglietti MJ (2000) Influence of hemolysis on the measurement of S-100beta protein and neuron-specific enolase plasma concentrations during coronary artery bypass grafting. Clin Chem 46: 989-990

14. Bellander BM, Olafsson IH, Ghatan PH, Bro Skejo HP, Hansson LO, Wanecek M, Svensson MA (2011) Secondary insults following traumatic brain injury enhance complement activation in the human brain and release of the tissue damage marker S100B. Acta Neurochir (Wien) 153:90-100

15. Ben Abdesselam O, Vally J, Adem C, Foglietti MJ, Beaudeux JL (2003) Reference values for serum S-100B protein depend on the race of individuals. Clin Chem 49:836-837

16. Berger RP (2006) The use of serum biomarkers to predict outcome after traumatic brain injury in adults and children. J Head Trauma Rehabil 21:315-333

17. Berger RP, Bazaco MC, Wagner AK, Kochanek PM, Fabio A (2010) Trajectory analysis of serum biomarker concentrations facilitates outcome prediction after pediatric traumatic and hypoxemic brain injury. Dev Neurosci 32:396-405

18. Berger RP, Kochanek PM (2006) Urinary S100B concentrations are increased after brain injury in children: a preliminary study. Pediatr Critic Care Med : J Soc Critic Care Med World Fed Pediatr Intens Critic Care Soc 7:557-561

19. Bloomfield SM, McKinney J, Smith L, Brisman J (2007) Reliability of S100B in predicting severity of central nervous system injury. Neurocrit Care 6:121-138

20. Blyth BJ, Farahvar A, He H, Nayak A, Yang C, Shaw G, Bazarian JJ (2011) Elevated serum ubiquitin carboxy-terminal hydrolase L1 is associated with abnormal blood-brain barrier function after traumatic brain injury. J Neurotrauma 28:2453-2462

21. Bouvier D, Castellani C, Fournier M, Dauphin JB, Ughetto S, Breton M, Labbe A, Weinberg AM, Sapin V (2011) Reference ranges for serum $\mathrm{S} 100 \mathrm{~B}$ protein during the first three years of life. Clin Biochem 44:927-929

22. Bouvier D, Fournier M, Dauphin JB, Amat F, Ughetto S, Labbe A, Sapin V (2012) Serum S100B determination in the management of pediatric mild traumatic brain injury. Clin Chem 58:1116-1122

23. Brea D, Sobrino T, Blanco M, Cristobo I, Rodriguez-Gonzalez R, Rodriguez-Yanez M, Moldes O, Agulla J, Leira R, Castillo J (2009) Temporal profile and clinical significance of serum neuron-specific enolase and S100 in ischemic and hemorrhagic stroke. Clin Chem Lab Med 47:1513-1518

24. Brenner DJ, Hall EJ (2007) Computed tomography-an increasing source of radiation exposure. N Engl J Med 357:2277-2284

25. Brewton LS, Haddad L, Azmitia EC (2001) Colchicine-induced cytoskeletal collapse and apoptosis in N-18 neuroblastoma cultures is rapidly reversed by applied S-100beta. Brain Res 912:916

26. Brophy GM, Mondello S, Papa L, Robicsek SA, Gabrielli A, Tepas J 3rd, Buki A, Robertson C, Tortella FC, Hayes RL, Wang KK (2011) Biokinetic analysis of ubiquitin C-terminal hydrolase-L1 (UCH-L1) in severe traumatic brain injury patient biofluids. J Neurotrauma 28:861-870

27. Calcagnile O, Anell A, Unden J (2016) The addition of S100B to guidelines for management of mild head injury is potentially cost saving. BMC Neurol 16:200

28. Carpenter KL, Czosnyka M, Jalloh I, Newcombe VF, Helmy A, Shannon RJ, Budohoski KP, Kolias AG, Kirkpatrick PJ, Carpenter TA, Menon DK, Hutchinson PJ (2015) Systemic, local, and imaging biomarkers of brain injury: more needed, and better use of those already established? Front Neurol 6:26

29. Cassidy JD, Carroll LJ, Peloso PM, Borg J, von Holst H, Holm L, Kraus J, Coronado VG, Injury WHOCCTFoMTB (2004) Incidence, risk factors and prevention of mild traumatic brain injury: results of the WHO Collaborating Centre Task Force on Mild Traumatic Brain Injury. J Rehabil Med:28-60

30. Castellani C, Stojakovic T, Cichocki M, Scharnagl H, Erwa W, Gutmann A, Weinberg AM (2008) Reference ranges for neuroprotein S-100B: from infants to adolescents. Clin Chem Lab Med 46:1296-1299

31. Cheng F, Yuan Q, Yang J, Wang W, Liu H (2014) The prognostic value of serum neuron-specific enolase in traumatic brain injury: systematic review and meta-analysis. PLoS One 9:e106680

32. Chiu FC, Goldman JE (1984) Synthesis and turnover of cytoskeletal proteins in cultured astrocytes. J Neurochem 42:166-174

33. da Rocha AB, Schneider RF, de Freitas GR, Andre C, Grivicich I, Zanoni C, Fossa A, Gehrke JT, Pereira Jotz G, Kaufmann M, Simon D, Regner A (2006) Role of serum S100B as a predictive marker of fatal outcome following isolated severe head injury or multitrauma in males. Clin Chem Lab Med 44:1234-1242

34. Diaz-Arrastia R, Wang KK, Papa L, Sorani MD, Yue JK, Puccio AM, McMahon PJ, Inoue T, Yuh EL, Lingsma HF, Maas AI, Valadka AB, Okonkwo DO, Manley GT (2014) Acute biomarkers of traumatic brain injury: relationship between plasma levels of ubiquitin C-terminal hydrolase-L1 and glial fibrillary acidic protein. J Neurotrauma 31:19-25

35. Dimopoulou I, Korfias S, Dafni U, Anthi A, Psachoulia C, Jullien G, Sakas DE, Roussos C (2003) Protein S-100b serum levels in trauma-induced brain death. Neurology 60:947-951

36. Donato R (2001) S100: a multigenic family of calcium-modulated proteins of the EF-hand type with intracellular and extracellular functional roles. Int J Biochem Cell Biol 33:637-668

37. Donato R (2003) Intracellular and extracellular roles of S100 proteins. Microsc Res Tech 60:540-551

38. Donato R, Cannon BR, Sorci G, Riuzzi F, Hsu K, Weber DJ, Geczy CL (2013) Functions of S100 proteins. Curr Mol Med 13:24-57 
39. Donato R, Sorci G, Riuzzi F, Arcuri C, Bianchi R, Brozzi F, Tubaro C, Giambanco I (2009) S100B's double life: intracellular regulator and extracellular signal. Biochim Biophys Acta 1793: $1008-1022$

40. Egberts F, Hitschler WN, Weichenthal M, Hauschild A (2009) Prospective monitoring of adjuvant treatment in high-risk melanoma patients: lactate dehydrogenase and protein S-100B as indicators of relapse. Melanoma Res 19:31-35

41. Egea-Guerrero JJ, Revuelto-Rey J, Gordillo-Escobar E, Rodriguez-Rodriguez A, Enamorado-Enamorado J, de Azua Lopez Ruiz Z, Aldabo-Pallas T, Leon-Justel A, Murillo-Cabezas F, Vilches-Arenas A (2013) Serologic behavior of S100B protein in patients who are brain dead: preliminary results. Transplant Proc 45:3569-3572

42. Ercole A, Thelin EP, Holst A, Bellander BM, Nelson DW (2016) Kinetic modelling of serum $\mathrm{S} 100 \mathrm{~b}$ after traumatic brain injury. BMC Neurol 16:93

43. Fazeli MS, Errington ML, Dolphin AC, Bliss TV (1990) Extracellular proteases and S100 protein in long-term potentiation in the dentate gyrus of the anaesthetized rat. Adv Exp Med Biol 268:369-375

44. Filippidis AS, Papadopoulos DC, Kapsalaki EZ, Fountas KN (2010) Role of the S100B serum biomarker in the treatment of children suffering from mild traumatic brain injury. Neurosurg Focus E2

45. Foerch C, Otto B, Singer OC, Neumann-Haefelin T, Yan B, Berkefeld J, Steinmetz H, Sitzer M (2004) Serum S100B predicts a malignant course of infarction in patients with acute middle cerebral artery occlusion. Stroke 35:2160-2164

46. Gao F, Harris DN, Sapsed-Byrne S, Sharp S (1997) Neuronespecific enolase and Sangtec 100 assays during cardiac surgery: part III-dose haemolysis affect their accuracy? Perfusion 12:171177

47. Gerlach R, Demel G, Konig HG, Gross U, Prehn JH, Raabe A, Seifert V, Kogel D (2006) Active secretion of S100B from astrocytes during metabolic stress. Neuroscience 141:1697-1701

48. Ghanem G, Loir B, Morandini R, Sales F, Lienard D, Eggermont A, Lejeune F (2001) On the release and half-life of S100B protein in the peripheral blood of melanoma patients. Int J Cancer 94:586590

49. Goncalves CA, Leite MC, Nardin P (2008) Biological and methodological features of the measurement of S100B, a putative marker of brain injury. Clin Biochem 41:755-763

50. Gonzclez-Mao MC, Reparaz-Andrade A, Del Campo-Perez V, Alvarez-Garcia E, Vara-Perez C, Andrade-Olivie MA (2011) Model predicting survival/exitus after traumatic brain injury: biomarker S100B 24h. Clin Lab 57:587-597

51. Goyal A, Failla MD, Niyonkuru C, Amin K, Fabio A, Berger RP, Wagner AK (2013) S100b as a prognostic biomarker in outcome prediction for patients with severe traumatic brain injury. J Neurotrauma 30:946-957

52. Gradisek P, Osredkar J, Korsic M, Kremzar B (2012) Multiple indicators model of long-term mortality in traumatic brain injury. Brain Inj

53. Graham EM, Burd I, Everett AD, Northington FJ (2016) Blood. Front Pharmacol 7:196

54. Group BDW (2001) Biomarkers and surrogate endpoints: preferred definitions and conceptual framework. Clin Pharmacol Ther 69:89-95

55. Gunnarsson M, Malmestrom C, Axelsson M, Sundstrom P, Dahle C, Vrethem M, Olsson T, Piehl F, Norgren N, Rosengren L, Svenningsson A, Lycke J (2011) Axonal damage in relapsing multiple sclerosis is markedly reduced by natalizumab. Ann Neurol 69:83-89

56. Gustavsson A, Svensson M, Jacobi F, Allgulander C, Alonso J, Beghi E, Dodel R, Ekman M, Faravelli C, Fratiglioni L, Gannon
B, Jones DH, Jennum P, Jordanova A, Jonsson L, Karampampa K, Knapp M, Kobelt G, Kurth T, Lieb R, Linde M, Ljungcrantz C, Maercker A, Melin B, Moscarelli M, Musayev A, Norwood F, Preisig M, Pugliatti M, Rehm J, Salvador-Carulla L, Schlehofer B, Simon R, Steinhausen HC, Stovner LJ, Vallat JM, Van den Bergh P, van Os J, Vos P, Xu W, Wittchen HU, Jonsson B, Olesen J (2011) Cost of disorders of the brain in Europe 2010. Eur Neuropsychopharmacol 21:718-779

57. Haglid KG, Yang Q, Hamberger A, Bergman S, Widerberg A, Danielsen N (1997) S-100beta stimulates neurite outgrowth in the rat sciatic nerve grafted with acellular muscle transplants. Brain Res 753:196-201

58. Haimoto H, Hosoda S, Kato K (1987) Differential distribution of immunoreactive S100-alpha and S100-beta proteins in normal nonnervous human tissues. Lab Invest 57:489-498

59. Hall P, Adami HO, Trichopoulos D, Pedersen NL, Lagiou P, Ekbom A, Ingvar M, Lundell M, Granath F (2004) Effect of low doses of ionising radiation in infancy on cognitive function in adulthood: Swedish population based cohort study. BMJ 328:19

60. Hamm CW, Goldmann BU, Heeschen C, Kreymann G, Berger J, Meinertz T (1997) Emergency room triage of patients with acute chest pain by means of rapid testing for cardiac troponin $\mathrm{T}$ or troponin I. N Engl J Med 337:1648-1653

61. Hawryluk GWJ, Bullock MR (2016) Past, Present, and future of traumatic brain injury research. Neurosurg Clin N Am

62. Hayakata T, Shiozaki T, Tasaki O, Ikegawa H, Inoue Y, Toshiyuki F, Hosotubo H, Kieko F, Yamashita T, Tanaka H, Shimazu T, Sugimoto H (2004) Changes in CSF S100B and cytokine concentrations in early-phase severe traumatic brain injury. Shock 22: $102-107$

63. Heidari K, Vafaee A, Rastekenari AM, Taghizadeh M, Shad EG, Eley R, Sinnott M, Asadollahi S (2015) S100B protein as a screening tool for computed tomography findings after mild traumatic brain injury: Systematic review and meta-analysis. Brain Inj:1-12

64. Heizmann CW, Fritz G, Schafer BW (2002) S100 proteins: structure, functions and pathology. Front Biosci : J Virtual Library 7: d1356-d1368

65. Hendoui N, Beigmohammadi MT, Mahmoodpoor A, Ahmadi A, Abdollahi M, Hasanpour M, Hadi F, Khazaeipour Z, Mousavi S, Mojtahedzadeh M (2013) Reliability of calcium-binding protein S100B measurement toward optimization of hyperosmolal therapy in traumatic brain injury. Europ Rev Med Pharmacol Sci 17: $477-485$

66. Hergenroeder GW, Redell JB, Moore AN, Dash PK (2008) Biomarkers in the clinical diagnosis and management of traumatic brain injury. Molec Diagnos Therap 12:345-358

67. Herrmann M, Jost S, Kutz S, Ebert AD, Kratz T, Wunderlich MT, Synowitz H (2000) Temporal profile of release of neurobiochemical markers of brain damage after traumatic brain injury is associated with intracranial pathology as demonstrated in cranial computerized tomography. J Neurotrauma 17:113-122

68. Hinkle DA, Baldwin SA, Scheff SW, Wise PM (1997) GFAP and S100beta expression in the cortex and hippocampus in response to mild cortical contusion. J Neurotrauma 14:729-738

69. Hu J, Ferreira A, Van Eldik LJ (1997) S100beta induces neuronal cell death through nitric oxide release from astrocytes. J Neurochem 69:2294-2301

70. Iliff JJ, Chen MJ, Plog BA, Zeppenfeld DM, Soltero M, Yang L, Singh I, Deane R, Nedergaard M (2014) Impairment of glymphatic pathway function promotes tau pathology after traumatic brain injury. J Neurosci 34:16180-16193

71. Iliff JJ, Wang M, Liao Y, Plogg BA, Peng W, Gundersen GA, Benveniste H, Vates GE, Deane R, Goldman SA, Nagelhus EA, Nedergaard M (2012) A paravascular pathway facilitates CSF flow through the brain parenchyma and the clearance of interstitial solutes, including amyloid beta. Sci Transl Med 4:147ra111 
72. Ingebrigtsen T, Romner B (1996) Serial S-100 protein serum measurements related to early magnetic resonance imaging after minor head injury. Case Report J Neurosurg 85:945-948

73. Ingebrigtsen T, Romner B (2002) Biochemical serum markers of traumatic brain injury. J Trauma 52:798-808

74. Ingebrigtsen T, Romner B, Kock-Jensen C (2000) Scandinavian guidelines for initial management of minimal, mild, and moderate head injuries. the Scandinavian Neurotrauma Committee. J Trauma 48:760-766

75. Ingebrigtsen T, Romner B, Kongstad P, Langbakk B (1995) Increased serum concentrations of protein S-100 after minor head injury: a biochemical serum marker with prognostic value? J Neurol Neurosurg Psychiatry 59:103-104

76. Isobe T, Ishioka N, Masuda T, Takahashi Y, Ganno S, Okuyama T (1983) A rapid separation of S100 subunits by high performance liquid chromatography: the subunit compositions of S100 proteins. Biochem Int 6:419-426

77. Jackson RG, Samra GS, Radcliffe J, Clark GH, Price CP (2000) The early fall in levels of S-100 beta in traumatic brain injury. Clin Chem Lab Med 38:1165-1167

78. Johnsson P, Blomquist S, Luhrs C, Malmkvist G, Alling C, Solem JO, Stahl E (2000) Neuron-specific enolase increases in plasma during and immediately after extracorporeal circulation. Ann Thorac Surg 69:750-754

79. Jonsson H, Johnsson P, Hoglund P, Alling C, Blomquist S (2000) Elimination of S100B and renal function after cardiac surgery. $\mathrm{J}$ Cardiothorac Vasc Anesth 14:698-701

80. Kanner AA, Marchi N, Fazio V, Mayberg MR, Koltz MT, Siomin V, Stevens GH, Masaryk T, Aumayr B, Vogelbaum MA, Barnett GH, Janigro D (2003) Serum S100beta: a noninvasive marker of blood-brain barrier function and brain lesions. Cancer 97:28062813

81. Kapural M, Krizanac-Bengez L, Barnett G, Perl J, Masaryk T, Apollo D, Rasmussen P, Mayberg MR, Janigro D (2002) Serum S-100beta as a possible marker of blood-brain barrier disruption. Brain Res 940:102-104

82. Kindblom LG, Lodding P, Rosengren L, Baudier J, Haglid K (1984) S-100 protein in melanocytic tumors. an immunohistochemical investigation of benign and malignant melanocytic tumors and metastases of malignant melanoma and a characterization of the antigen in comparison to human brain. Acta Pathol, Microbiol, et Immunol Scandinavica Sect A, Pathol 92:219-230

83. Kleindienst A, Grunbeck F, Buslei R, Emtmann I, Buchfelder M (2013) Intraperitoneal treatment with S100B enhances hippocampal neurogenesis in juvenile mice and after experimental brain injury. Acta Neurochir (Wien) 155:1351-1360

84. Kleindienst A, Hesse F, Bullock MR, Buchfelder M (2007) The neurotrophic protein S100B: value as a marker of brain damage and possible therapeutic implications. Prog Brain Res 161:317325

85. Kleindienst A, Meissner S, Eyupoglu IY, Parsch H, Schmidt C, Buchfelder M (2010) Dynamics of S100B release into serum and cerebrospinal fluid following acute brain injury. Acta Neurochir Suppl 106:247-250

86. Kleindienst A, Ross Bullock M (2006) A critical analysis of the role of the neurotrophic protein S100B in acute brain injury. $\mathrm{J}$ Neurotrauma 23:1185-1200

87. Kleindienst A, Schmidt C, Parsch H, Emtmann I, Xu Y, Buchfelder M (2010) The passage of S100B from brain to blood is not specifically related to the blood-brain barrier integrity. Cardiovasc Psychiatr Neurol 2010:801295

88. Kochanek PM, Berger RP, Bayir H, Wagner AK, Jenkins LW, Clark RS (2008) Biomarkers of primary and evolving damage in traumatic and ischemic brain injury: diagnosis, prognosis, probing mechanisms, and therapeutic decision making. Curr Opin Crit Care 14:135-141
89. Koppal T, Lam AG, Guo L, Van Eldik LJ (2001) S100B proteins that lack one or both cysteine residues can induce inflammatory responses in astrocytes and microglia. Neurochem Int 39:401-407

90. Korfias S, Stranjalis G, Boviatsis E, Psachoulia C, Jullien G, Gregson B, Mendelow AD, Sakas DE (2007) Serum S-100B protein monitoring in patients with severe traumatic brain injury. Intensive Care Med 33:255-260

91. Korfias S, Stranjalis G, Papadimitriou A, Psachoulia C, Daskalakis G, Antsaklis A, Sakas DE (2006) Serum S-100B protein as a biochemical marker of brain injury: a review of current concepts. Curr Med Chem 13:3719-3731

92. Kovesdi E, Luckl J, Bukovics P, Farkas O, Pal J, Czeiter E, Szellar D, Doczi T, Komoly S, Buki A (2010) Update on protein biomarkers in traumatic brain injury with emphasis on clinical use in adults and pediatrics. Acta Neurochir (Wien) 152:1-17

93. Lee H, Wintermark M, Gean AD, Ghajar J, Manley GT, Mukherjee P (2008) Focal lesions in acute mild traumatic brain injury and neurocognitive outcome: CT versus 3 T MRI. J Neurotrauma 25:1049-1056

94. Li ZM, Xiao YL, Zhu JX, Geng FY, Guo CJ, Chong ZL, Wang LX (2016) Recombinant human erythropoietin improves functional recovery in patients with severe traumatic brain injury: a randomized, double blind and controlled clinical trial. Clin Neurol Neurosurg 150:80-83

95. Liu MC, Akinyi L, Scharf D, Mo J, Larner SF, Muller U, Oli MW, Zheng W, Kobeissy F, Papa L, Lu XC, Dave JR, Tortella FC, Hayes RL, Wang KK (2010) Ubiquitin C-terminal hydrolase-L1 as a biomarker for ischemic and traumatic brain injury in rats. Eur J Neurosci 31:722-732

96. Lomas JP, Dunning J (2005) Best evidence topic report. S-100b protein levels as a predictor for long-term disability after head injury. Emerg Med J 22:889-891

97. Lopez NE, Krzyzaniak MJ, Blow C, Putnam J, Ortiz-Pomales Y, Hageny AM, Eliceiri B, Coimbra R, Bansal V (2012) Ghrelin prevents disruption of the blood-brain barrier after traumatic brain injury. J Neurotrauma 29:385-393

98. Maas AI, Hukkelhoven CW, Marshall LF, Steyerberg EW (2005) Prediction of outcome in traumatic brain injury with computed tomographic characteristics: a comparison between the computed tomographic classification and combinations of computed tomographic predictors. Neurosurgery 57:1173-1182, discussion 11731182

99. Marchi N, Fazio V, Cucullo L, Kight K, Masaryk T, Barnett G, Vogelbaum M, Kinter M, Rasmussen P, Mayberg MR, Janigro D (2003) Serum transthyretin monomer as a possible marker of blood-to-CSF barrier disruption. J Neurosci 23:1949-1955

100. Marmarou A (2003) Pathophysiology of traumatic brain edema: current concepts. Acta Neurochir Suppl 86:7-10

101. Marshall LF, Marshall SB, Klauber MR, Clark MV, Eisenberg HM, Jane JA, Luerssen TG, Marmarou A, Foulkes MA (1991) A new classification of head-injury based on computerized-tomography. J Neurosurg 75:S14-S20

102. Masel BE, DeWitt DS (2010) Traumatic brain injury: a disease process, not an event. J Neurotrauma 27:1529-1540

103. McAdory BS, Van Eldik LJ, Norden JJ (1998) S100B, a neurotropic protein that modulates neuronal protein phosphorylation, is upregulated during lesion-induced collateral sprouting and reactive synaptogenesis. Brain Res 813:211-217

104. Mercier E, Boutin A, Lauzier F, Fergusson DA, Simard JF, Zarychanski R, Moore L, McIntyre LA, Archambault P, Lamontagne F, Legare F, Randell E, Nadeau L, Rousseau F, Turgeon AF (2013) Predictive value of S-100beta protein for prognosis in patients with moderate and severe traumatic brain injury: systematic review and meta-analysis. BMJ 346:f1757

105. Mercier E, Boutin A, Shemilt M, Lauzier F, Zarychanski R, Fergusson DA, Moore L, McIntyre LA, Archambault P, Legare 
F, Rousseau F, Lamontagne F, Nadeau L, Turgeon AF (2016) Predictive value of neuron-specific enolase for prognosis in patients with moderate or severe traumatic brain injury: a systematic review and meta-analysis. CMAJ 4:E371-E382

106. Michetti F, Corvino V, Geloso MC, Lattanzi W, Bernardini C, Serpero L, Gazzolo D (2012) The S100B protein in biological fluids: more than a lifelong biomarker of brain distress. J Neurochem 120:644-659

107. Molina R, Navarro J, Filella X, Castel T, Ballesta AM (2002) S100 protein serum levels in patients with benign and malignant diseases: false-positive results related to liver and renal function. Tumour Biol 23:39-44

108. Moore BW (1965) A soluble protein characteristic of the nervous system. Biochem Biophys Res Commun 19:739-744

109. Moritz S, Warnat J, Bele S, Graf BM, Woertgen C (2010) The prognostic value of NSE and S100B from serum and cerebrospinal fluid in patients with spontaneous subarachnoid hemorrhage. $\mathrm{J}$ Neurosurg Anesthesiol 22:21-31

110. Mortberg E, Zetterberg H, Nordmark J, Blennow K, Rosengren L, Rubertsson S (2011) S-100B is superior to NSE, BDNF and GFAP in predicting outcome of resuscitation from cardiac arrest with hypothermia treatment. Resuscitation 82:26-31

111. Mower WR, Hoffman JR, Herbert M, Wolfson AB, Pollack CV Jr, Zucker MI (2002) Developing a clinical decision instrument to rule out intracranial injuries in patients with minor head trauma: methodology of the NEXUS II investigation. Ann Emerg Med 40:505-514

112. Muller K, Townend W, Biasca N, Unden J, Waterloo K, Romner B, Ingebrigtsen T (2007) S100B serum level predicts computed tomography findings after minor head injury. J Trauma 62:14521456

113. Murillo-Cabezas F, Munoz-Sanchez MA, Rincon-Ferrari MD, Martin-Rodriguez JF, Amaya-Villar R, Garcia-Gomez S, LeonCarrion J (2010) The prognostic value of the temporal course of S100beta protein in post-acute severe brain injury: a prospective and observational study. Brain Inj 24:609-619

114. Murray GD, Butcher I, McHugh GS, Lu J, Mushkudiani NA, Maas AI, Marmarou A, Steyerberg EW (2007) Multivariable prognostic analysis in traumatic brain injury: results from the IMPACT study. J Neurotrauma 24:329-337

115. Mussack T, Biberthaler P, Kanz KG, Wiedemann E, GippnerSteppert C, Mutschler W, Jochum M (2002) Serum S-100B and interleukin- 8 as predictive markers for comparative neurologic outcome analysis of patients after cardiac arrest and severe traumatic brain injury. Crit Care Med 30:2669-2674

116. Mussack T, Klauss V, Ruppert V, Gippner-Steppert C, Biberthaler P, Schiemann U, Hoffmann U, Jochum M (2006) Rapid measurement of S-100B serum protein levels by Elecsys S100 immunoassay in patients undergoing carotid artery stenting or endarterectomy. Clin Biochem 39:349-356

117. Nelson DW, Nystrom H, MacCallum RM, Thornquist B, Lilja A, Bellander BM, Rudehill A, Wanecek M, Weitzberg E (2010) Extended analysis of early computed tomography scans of traumatic brain injured patients and relations to outcome. J Neurotrauma 27:51-64

118. Neselius S, Brisby H, Theodorsson A, Blennow K, Zetterberg H, Marcusson J (2012) CSF-biomarkers in Olympic boxing: diagnosis and effects of repetitive head trauma. PLoS One 7:e33606

119. Nichol A, French C, Little L, Haddad S, Presneill J, Arabi Y, Bailey M, Cooper DJ, Duranteau J, Huet O, Mak A, McArthur C, Pettila V, Skrifvars M, Vallance S, Varma D, Wills J, Bellomo R (2015) Erythropoietin in traumatic brain injury (EPO-TBI): a double-blind randomised controlled trial. Lancet 386:2499-2506

120. Nishiyama H, Knopfel T, Endo S, Itohara S (2002) Glial protein S100B modulates long-term neuronal synaptic plasticity. Proc Natl Acad Sci U S A 99:4037-4042
121. Niyonkuru C, Wagner AK, Ozawa H, Amin K, Goyal A, Fabio A (2013) Group-based trajectory analysis applications for prognostic biomarker model development in severe TBI: a practical example. J Neurotrauma 30:938-945

122. North SH, Shriver-Lake LC, Taitt CR, Ligler FS (2012) Rapid analytical methods for on-site triage for traumatic brain injury. Annu Rev Anal Chem (Palo Alto, Calif) 5:35-56

123. Oertel M, Schumacher U, McArthur DL, Kastner S, Boker DK (2006) S-100B and NSE: markers of initial impact of subarachnoid haemorrhage and their relation to vasospasm and outcome. J Clin Neurosci 13:834-840

124. Olivecrona Z, Bobinski L, Koskinen LO (2014) Association of ICP, CPP, CT findings and S-100B and NSE in severe traumatic head injury. Prognostic value of the biomarkers. Brain Inj:1-9

125. Olson-Madden JH, Brenner LA, Corrigan JD, Emrick CD, Britton PC (2012) Substance use and mild traumatic brain injury risk reduction and prevention: a novel model for treatment. Rehabil Res Pract 2012:174579

126. Omalu BI, DeKosky ST, Minster RL, Kamboh MI, Hamilton RL, Wecht CH (2005) Chronic traumatic encephalopathy in a National Football League player. Neurosurgery 57:128-134, discussion 128-134

127. Papa L, Brophy GM, Welch RD, Lewis LM, Braga CF, Tan CN, Ameli NJ, Lopez MA, Haeussler CA, Mendez Giordano DI, Silvestri S, Giordano P, Weber KD, Hill-Pryor C, Hack DC (2016) Time course and diagnostic accuracy of glial and neuronal blood biomarkers GFAP and UCH-L1 in a large cohort of trauma patients with and without mild traumatic brain injury. JAMA Neurol

128. Papa L, Lewis LM, Silvestri S, Falk JL, Giordano P, Brophy GM, Demery JA, Liu MC, Mo J, Akinyi L, Mondello S, Schmid K, Robertson CS, Tortella FC, Hayes RL, Wang KK (2012) Serum levels of ubiquitin $\mathrm{C}$-terminal hydrolase distinguish mild traumatic brain injury from trauma controls and are elevated in mild and moderate traumatic brain injury patients with intracranial lesions and neurosurgical intervention. J Trauma Acute Care Surg 72: 1335-1344

129. Papa L, Ramia MM, Edwards D, Johnson BD, Slobounov SM (2015) Systematic review of clinical studies examining biomarkers of brain injury in athletes after sports-related concussion. J Neurotrauma 32:661-673

130. Papa L, Robinson G, Oli M, Pineda J, Demery J, Brophy G, Robicsek SA, Gabrielli A, Robertson CS, Wang KK, Hayes RL (2008) Use of biomarkers for diagnosis and management of traumatic brain injury patients. Expert Opin Med Diagnost 2:937-945

131. Papa L, Silvestri S, Brophy GM, Giordano P, Falk JL, Braga CF, Tan CN, Ameli NJ, Demery JA, Dixit NK, Mendes ME, Hayes RL, Wang KK, Robertson CS (2014) GFAP out-performs S100beta in detecting traumatic intracranial lesions on computed tomography in trauma patients with mild traumatic brain injury and those with extracranial lesions. J Neurotrauma 31:1815-1822

132. Pelinka LE, Kroepfl A, Leixnering M, Buchinger W, Raabe A, Redl H (2004) GFAP versus S100B in serum after traumatic brain injury: relationship to brain damage and outcome. J Neurotrauma 21:1553-1561

133. Pelinka LE, Kroepfl A, Schmidhammer R, Krenn M, Buchinger W, Redl H, Raabe A (2004) Glial fibrillary acidic protein in serum after traumatic brain injury and multiple trauma. J Trauma 57: 1006-1012

134. Pelinka LE, Toegel E, Mauritz W, Redl H (2003) Serum S 100 B: a marker of brain damage in traumatic brain injury with and without multiple trauma. Shock 19:195-200

135. Persson ME, Thelin EP, Bellander BM (2012) Case report: extreme levels of serum S-100B in a patient with chronic subdural hematoma. Front Neurol 3:170 
136. Petzold A, Green AJ, Keir G, Fairley S, Kitchen N, Smith M, Thompson EJ (2002) Role of serum S100B as an early predictor of high intracranial pressure and mortality in brain injury: a pilot study. Crit Care Med 30:2705-2710

137. Petzold A, Keir G, Lim D, Smith M, Thompson EJ (2003) Cerebrospinal fluid (CSF) and serum S100B: release and washout pattern. Brain Res Bull 61:281-285

138. Pfortmueller CA, Drexel C, Krahenmann-Muller S, Leichtle AB, Fiedler GM, Lindner G, Exadaktylos AK (2016) S-100 B concentrations are a predictor of decreased survival in patients with major trauma, independently of head injury. PLoS One 11:e0152822

139. Pham N, Fazio V, Cucullo L, Teng Q, Biberthaler P, Bazarian JJ, Janigro D (2010) Extracranial sources of S100B do not affect serum levels. PLoS One 5

140. Pleines UE, Morganti-Kossmann MC, Rancan M, Joller H, Trentz O, Kossmann T (2001) S-100 beta reflects the extent of injury and outcome, whereas neuronal specific enolase is a better indicator of neuroinflammation in patients with severe traumatic brain injury. $\mathrm{J}$ Neurotrauma 18:491-498

141. Plog BA, Dashnaw ML, Hitomi E, Peng W, Liao Y, Lou N, Deane R, Nedergaard M (2015) Biomarkers of traumatic injury are transported from brain to blood via the glymphatic system. J Neurosci 35:518-526

142. Posti JP, Takala RS, Runtti H, Newcombe VF, Outtrim J, Katila AJ, Frantzen J, Ala-Seppala H, Coles JP, Hossain MI, Kyllonen A, Maanpaa HR, Tallus J, Hutchinson PJ, van Gils M, Menon DK, Tenovuo O (2016) The levels of glial fibrillary acidic protein and ubiquitin C-terminal hydrolase-L1 during the first week after a traumatic brain injury: correlations with clinical and imaging findings. Neurosurgery

143. Puvenna V, Brennan C, Shaw G, Yang C, Marchi N, Bazarian JJ, Merchant-Borna K, Janigro D (2014) Significance of ubiquitin carboxy-terminal hydrolase L1 elevations in athletes after subconcussive head hits. PLoS One 9:e96296

144. Raabe A, Grolms C, Keller M, Dohnert J, Sorge O, Seifert V (1998) Correlation of computed tomography findings and serum brain damage markers following severe head injury. Acta Neurochir (Wien) 140:787-791, discussion 791-782

145. Raabe A, Grolms C, Sorge O, Zimmermann M, Seifert V (1999) Serum S-100B protein in severe head injury. Neurosurgery 45 : 477-483

146. Raabe A, Kopetsch O, Gross U, Zimmermann M, Gebhart P (2003) Measurements of serum S-100B protein: effects of storage time and temperature on pre-analytical stability. Clin Chem Lab Med 41:700-703

147. Raabe A, Kopetsch O, Woszczyk A, Lang J, Gerlach R, Zimmermann M, Seifert V (2003) Serum S-100B protein as a molecular marker in severe traumatic brain injury. Restor Neurol Neurosci 21:159-169

148. Raabe A, Kopetsch O, Woszczyk A, Lang J, Gerlach R, Zimmermann M, Seifert V (2004) S-100B protein as a serum marker of secondary neurological complications in neurocritical care patients. Neurol Res 26:440-445

149. Raabe A, Seifert V (2000) Protein S-100B as a serum marker of brain damage in severe head injury: preliminary results. Neurosurg Rev 23:136-138

150. Roberts I, Yates D, Sandercock P, Farrell B, Wasserberg J, Lomas G, Cottingham R, Svoboda P, Brayley N, Mazairac G, Laloe V, Munoz-Sanchez A, Arango M, Hartzenberg B, Khamis H, Yutthakasemsunt S, Komolafe E, Olldashi F, Yadav Y, Murillo-Cabezas F, Shakur H, Edwards P (2004) Effect of intravenous corticosteroids on death within 14 days in 10008 adults with clinically significant head injury (MRC CRASH trial): randomised placebo-controlled trial. Lancet 364:1321-1328
151. Rolland B, Le Prince G, Fages C, Nunez J, Tardy M (1990) GFAP turnover during astroglial proliferation and differentiation. Brain Res Dev Brain Res 56:144-149

152. Romner B, Ingebrigtsen T, Kongstad P, Borgesen SE (2000) Traumatic brain damage: serum S-100 protein measurements related to neuroradiological findings. J Neurotrauma 17:641-647

153. Roozenbeek B, Maas AI, Menon DK (2013) Changing patterns in the epidemiology of traumatic brain injury. Nat Rev Neurol 9: 231-236

154. Rothermundt M, Peters M, Prehn JH, Arolt V (2003) S100B in brain damage and neurodegeneration. Microsc Res Tech 60:614 632

155. Routsi C, Stamataki E, Nanas S, Psachoulia C, Stathopoulos A, Koroneos A, Zervou M, Jullien G, Roussos C (2006) Increased levels of serum S100B protein in critically ill patients without brain injury. Shock 26:20-24

156. Sanchez-Pena P, Pereira AR, Sourour NA, Biondi A, Lejean L, Colonne C, Boch AL, Al Hawari M, Abdennour L, Puybasset L (2008) S100B as an additional prognostic marker in subarachnoid aneurysmal hemorrhage. Crit Care Med 36:2267-2273

157. Savola O, Pyhtinen J, Leino TK, Siitonen S, Niemela O, Hillbom $M$ (2004) Effects of head and extracranial injuries on serum protein S100B levels in trauma patients. J Trauma 56:1229-1234, discussion 1234

158. Schafer BW, Heizmann CW (1996) The S100 family of EF-hand calcium-binding proteins: functions and pathology. Trends Biochem Sci 21:134-140

159. Schiavi P, Laccarino C, Servadei F (2012) The value of the calcium binding protein $\mathrm{S} 100$ in the management of patients with traumatic brain injury. Acta Bio-Medica : Atenei Parmensis 83:5-20

160. Schmechel D, Marangos PJ, Brightman M (1978) Neuronespecific enolase is a molecular marker for peripheral and central neuroendocrine cells. Nature 276:834-836

161. Schulte S, Podlog LW, Hamson-Utley JJ, Strathmann FG, Struder HK (2014) A systematic review of the biomarker S100B: implications for sport-related concussion management. J Athl Train 49: $830-850$

162. Sen J, Belli A (2007) S100B in neuropathologic states: the CRP of the brain? J Neurosci Res 85:1373-1380

163. Serpero LD, Pluchinotta F, Gazzolo D (2015) The clinical and diagnostic utility of S100B in preterm newborns. Clin Chim Acta 444:193-198

164. Shakeri M, Mahdkhah A, Panahi F (2013) S100B protein as a post-traumatic biomarker for prediction of brain death in association with patient outcomes. Arch Trauma Res 2:76-80

165. Sindic CJ, Chalon MP, Cambiaso CL, Laterre EC, Masson PL (1982) Assessment of damage to the central nervous system by determination of S-100 protein in the cerebrospinal fluid. J Neurol Neurosurg Psychiatry 45:1130-1135

166. Sjostedt E, Fagerberg L, Hallstrom BM, Haggmark A, Mitsios N, Nilsson P, Ponten F, Hokfelt T, Uhlen M, Mulder J (2015) Defining the human brain proteome using transcriptomics and antibody-based profiling with a focus on the cerebral cortex. PLoS One 10:e130028

167. Smit LH, Korse CM, Bonfrer JM (2005) Comparison of four different assays for determination of serum S-100B. Int J Biol Markers 20:34-42

168. Smit LH, Nieweg OE, Mooi WJ, Bonfrer JM, Haanen JB, Kroon BB, De Gast GC (2008) Value of serum S-100B for prediction of distant relapse and survival in stage III B/C melanoma. Anticancer Res 28:2297-2302

169. Smith ME, Perret V, Eng LF (1984) Metabolic studies in vitro of the CNS cytoskeletal proteins: synthesis and degradation. Neurochem Res 9:1493-1507

170. Snow RB, Zimmerman RD, Gandy SE, Deck MD (1986) Comparison of magnetic resonance imaging and computed 
tomography in the evaluation of head injury. Neurosurgery 18 : $45-52$

171. Stein SC, Fabbri A, Servadei F, Glick HA (2009) A critical comparison of clinical decision instruments for computed tomographic scanning in mild closed traumatic brain injury in adolescents and adults. Ann Emerg Med 53:180-188

172. Steiner J, Bernstein HG, Bielau H, Berndt A, Brisch R, Mawrin C, Keilhoff G, Bogerts B (2007) Evidence for a wide extra-astrocytic distribution of S100B in human brain. BMC Neurosci 8:2

173. Stiell IG, Wells GA, Vandemheen K, Clement C, Lesiuk H, Laupacis A, McKnight RD, Verbeek R, Brison R, Cass D, Eisenhauer ME, Greenberg G, Worthington J (2001) The Canadian CT head rule for patients with minor head injury. Lancet 357:1391-1396

174. Stranjalis G, Korfias S, Papapetrou C, Kouyialis A, Boviatsis E, Psachoulia C, Sakas DE (2004) Elevated serum S-100B protein as a predictor of failure to short-term return to work or activities after mild head injury. J Neurotrauma 21:1070-1075

175. Stranjalis G, Korfias S, Psachoulia C, Kouyialis A, Sakas DE, Mendelow AD (2007) The prognostic value of serum S-100B protein in spontaneous subarachnoid haemorrhage. Acta Neurochir (Wien) 149:231-237, discussion 237-238

176. Stroick M, Fatar M, Ragoschke-Schumm A, Fassbender K, Bertsch T, Hennerici MG (2006) Protein S-100B-a prognostic marker for cerebral damage. Curr Med Chem 13:3053-3060

177. Thelin E, Bellander BM (2009) The temporal profiles in serum concentrations of S100B after traumatic brain injury correspond to outcome. J Neurotrauma 26:A44-A44

178. Thelin EP, Bellander BM, Nekludov M (2015) Biochemical response to hyperbaric oxygen treatment of a transhemispheric penetrating cerebral gunshot injury. Front Neurol 6:62

179. Thelin EP, Jeppsson E, Frostell A, Svensson M, Mondello S, Bellander BM, Nelson DW (2016) Utility of neuron-specific enolase in traumatic brain injury; relations to S100B levels, outcome, and extracranial injury severity. Crit Care 20:285

180. Thelin EP, Johannesson L, Nelson D, Bellander BM (2013) S100B is an important outcome predictor in traumatic brain injury. J Neurotrauma 30:519-528

181. Thelin EP, Nelson DW, Bellander BM (2014) Secondary peaks of S100B in serum relate to subsequent radiological pathology in traumatic brain injury. Neurocrit Care 20:217-229

182. Thelin EP, Zibung E, Riddez L, Nordenvall C (2015) Assessing bicycle-related trauma using the biomarker S100B reveals a correlation with total injury severity. Eur J Trauma Emerg Surg

183. Thompson WH, Thelin EP, Lilja A, Bellander BM, Fransson P (2016) Functional resting-state fMRI connectivity correlates with serum levels of the S100B protein in the acute phase of traumatic brain injury. Neuroimage Clin

184. Tibbling G, Link H, Ohman S (1977) Principles of albumin and $\mathrm{IgG}$ analyses in neurological disorders. I. establishment of reference values. Scand J Clin Lab Invest 37:385-390

185. Tolan NV, Vidal-Folch N, Algeciras-Schimnich A, Singh RJ, Grebe SK (2013) Individualized correction of neuron-specific enolase (NSE) measurement in hemolyzed serum samples. Clin Chim Acta 424:216-221

186. Townend W, Ingebrigtsen T (2006) Head injury outcome prediction: a role for protein S-100B? Injury 37:1098-1108

187. Ueno T, Iguro Y, Yamamoto H, Sakata R, Kakihana Y, Nakamura K (2003) Serial measurement of serum S-100B protein as a marker of cerebral damage after cardiac surgery. Ann Thorac Surg 75: 1892-1897, discussion 1897-1898

188. Unden J, Astrand R, Waterloo K, Ingebrigtsen T, Bellner J, Reinstrup P, Andsberg G, Romner B (2007) Clinical significance of serum S100B levels in neurointensive care. Neurocrit Care 6: 94-99
189. Unden J, Bellner J, Astrand R, Romner B (2005) Serum S100B levels in patients with epidural haematomas. Br J Neurosurg 19: 43-45

190. Unden J, Bellner J, Eneroth M, Alling C, Ingebrigtsen T, Romner B (2005) Raised serum S100B levels after acute bone fractures without cerebral injury. J Trauma 58:59-61

191. Unden J, Bellner J, Reinstrup P, Romner B (2004) Serial S100B levels before, during and after cerebral herniation. Br J Neurosurg $18: 277-280$

192. Unden J, Ingebrigtsen T, Romner B, Scandinavian Neurotrauma C (2013) Scandinavian guidelines for initial management of minimal, mild and moderate head injuries in adults: an evidence and consensus-based update. BMC Med 11:50

193. Unden J, Romner B (2010) Can low serum levels of S100B predict normal CT findings after minor head injury in adults?: an evidence-based review and meta-analysis. J Head Trauma Rehabil 25:228-240

194. Unden L, Calcagnile O, Unden J, Reinstrup P, Bazarian J (2015) Validation of the Scandinavian guidelines for initial management of minimal, mild and moderate traumatic brain injury in adults. BMC Med 13:292

195. Usui A, Kato K, Abe T, Murase M, Tanaka M, Takeuchi E (1989) S-100ao protein in blood and urine during open-heart surgery. Clin Chem 35:1942-1944

196. Van Eldik LJ, Wainwright MS (2003) The Janus face of glialderived S100B: beneficial and detrimental functions in the brain. Restor Neurol Neurosci 21:97-108

197. Watt SE, Shores EA, Baguley IJ, Dorsch N, Fearnside MR (2006) Protein S-100 and neuropsychological functioning following severe traumatic brain injury. Brain Inj 20:1007-1017

198. Wells PS, Owen C, Doucette S, Fergusson D, Tran H (2006) Does this patient have deep vein thrombosis? JAMA 295:199-207

199. Velmahos GC, Gervasini A, Petrovick L, Dorer DJ, Doran ME, Spaniolas K, Alam HB, De Moya M, Borges LF, Conn AK (2006) Routine repeat head $\mathrm{CT}$ for minimal head injury is unnecessary. $\mathrm{J}$ Trauma 60:494-499, discussion 499-501

200. Willoughby KA, Kleindienst A, Muller C, Chen T, Muir JK, Ellis EF (2004) S100B protein is released by in vitro trauma and reduces delayed neuronal injury. J Neurochem 91:1284-1291

201. Woertgen C, Rothoerl RD, Brawanski A (2002) Early S-100B serum level correlates to quality of life in patients after severe head injury. Brain Inj 16:807-816

202. Wolf H, Frantal S, Pajenda G, Leitgeb J, Sarahrudi K, Hajdu S (2015) Analysis of S100 calcium binding protein B serum levels in different types of traumatic intracranial lesions. J Neurotrauma 32:23-27

203. Woods SD, Flores R, Roberson PK, Lowery JD, Skinner RD, Culp WC (2011) Decreased serum levels of S-100B protein reflect successful treatment effects in a rabbit model of acute ischemic stroke. Open Neurol J 5:55-57

204. Vos PE, Lamers KJ, Hendriks JC, van Haaren M, Beems T, Zimmerman C, van Geel W, de Reus H, Biert J, Verbeek MM (2004) Glial and neuronal proteins in serum predict outcome after severe traumatic brain injury. Neurology 62:1303-1310

205. Wright DW, Yeatts SD, Silbergleit R, Palesch YY, Hertzberg VS, Frankel M, Goldstein FC, Caveney AF, Howlett-Smith H, Bengelink EM, Manley GT, Merck LH, Janis LS, Barsan WG, Investigators N (2014) Very early administration of progesterone for acute traumatic brain injury. N Engl J Med 371: 2457-2466

206. Yokobori S, Hosein K, Burks S, Sharma I, Gajavelli S, Bullock R (2013) Biomarkers for the clinical differential diagnosis in traumatic brain injury-a systematic review. CNS Neurosci Ther 19: $556-565$ 